Article

\title{
Application of Life-cycle Assessment for the study of carbon and water footprints of the 16.5 MWe wind farm in Villonaco, Loja - Ecuador
}

\author{
Alberto Tama Franco 1, 2,* \\ 1 UNIBA, University of Barcelona, Av. Josep Tarradellas i Joan, 179, L'Hospitalet de Llobregat, Barcelona, \\ 08901, Spain. \\ 2 Faculty of Electrical and Computer Engineering, ESPOL, Campus Gustavo Galindo Velasco, km. 30.5 vía \\ Perimetral, Guayas, Guayaquil, 090150, Ecuador. \\ * Tel.: +593 99642 2734, E-mail address: atama@espol.edu.ec
}

\begin{abstract}
Wind technology is considered to be among the most promising types of renewable energy sources, and due to high oil prices and growing concerns about climate change and energy security, it has been the subject of extensive considerations in recent years, including questions related to the relative sustainability of electricity production when the manufacturing, assembly, transportation and dismantling processes of these facilities are taken into account. The present article evaluates the environmental impacts, carbon emissions and water consumption, derived from the production of electric energy of the Villonaco wind farm, located in Loja-Ecuador, during its entire life cycle, using the Life Cycle Analysis method. Finally, it is concluded that wind energy has greater environmental advantages, since it has lower values of carbon and water footprints than other energy sources. Additionally, with the techniques Cumulative Energy Demand and Energy Return on Investment, sustainability in the production of electricity from wind power in Ecuador is demonstrated; and, that due to issues of vulnerability to climate change, the diversification of its energy mix is essential considering the inclusion of non-conventional renewable sources such as solar or wind, this being the only way to reduce both the carbon footprint and the water supply power.
\end{abstract}

Keywords: Renewable energy; Life cycle analysis; Wind energy; Life cycle assessment; Wind turbine; Carbon footprint; Water consumption; Greenhouse gases; non-conventional renewable sources; Carbon and water footprints.

\section{Introduction}

"The development of cleaner and efficient energy technologies and the use of new renewable energy sources will play an important role in the sustainable development of a future energy strategy. The promotion of renewable energy sources and the development of cleaner and more efficient energy systems are of high priority for security and diversification of energy supply, environmental protection, and social and economic cohesion" [1]

In 2020, the top five markets for which the wind energy was the fastest growing renewable energy sector were: China, USA, Brazil, Norway and Germany (Figure 1). Indeed, and despite the pandemic due to COVID-19, the capacity of new wind power installations worldwide increased by a value of $93 \mathrm{GW}$, representing a growth of 53\% compared to 2019. "This extraordinary increase was undoubtedly driven primarily by explosive growth in the world's two largest wind markets, China and the United States." [2]. The cardinal motivation for the adoption of this technology is largely due to the search for low-carbon forms of energy that allow less dependence on fossil fuels $[3,4]$. 

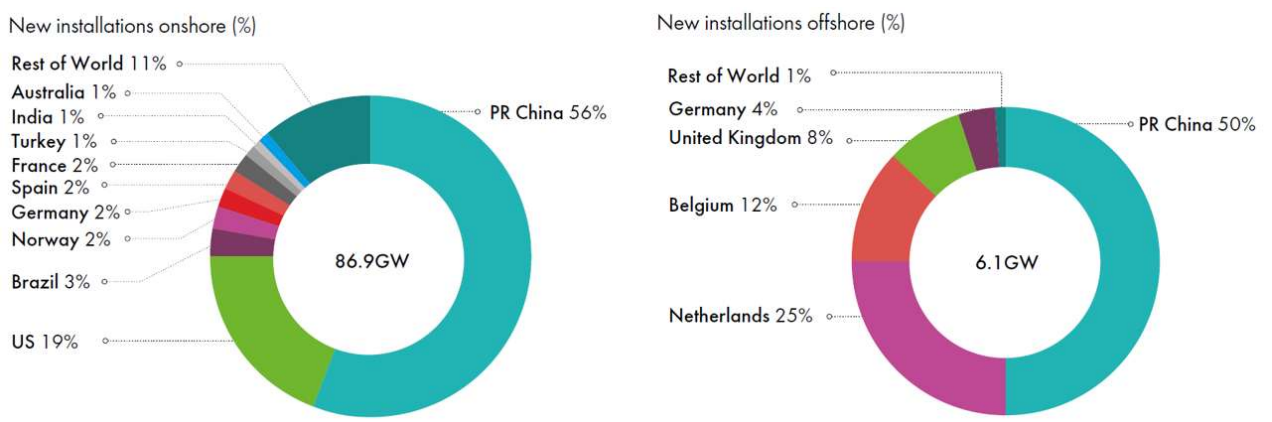

Figure 1. New installations 2020 and share of onshore and offshore market [2].

"Sustainable development responds to the needs of the present moment without jeopardizing or compromising the ability of future generations to meet their own needs" $[1,5]$. From the energy point of view, sustainable development is only possible if the energy system is also sustainable, and the latter must be based on renewable energies and policies that promote energy efficiency and savings. Starting with the premise of utilizing kinetic wind energy for the purpose of generating a clean form of electricity, wind energy seems to be the ideal solution to this problem. However, this technology has recently been examined due to questions raised about the relative sustainability of wind energy when manufacturing, transport and disposal processes are taken into account $[3,6,7]$. In this way, and taking into account that wind turbines are manufactured with a combination of metals, concrete and fiberglass, as well as the processes associated with transportation, installation and dismantling, it is undeniable that during the stages of their life cycle, an appreciable amount of energy, derived from fossil fuels, will be required.

A recommended tool for quantifying the environmental impacts of a renewable energy system, at all stages of its useful life, is undoubtedly the Life Cycle Assessment (LCA), which also allows for a more accurate comparison between such a system and a conventional one. This article applies this tool to a wind turbine belonging to a wind farm in Ecuador, located in the region of Villonaco, in the province of Loja, and thus evaluates the emissions associated with its life cycle.

\section{Goal and scope definition}

The main goal of this study is to evaluate and weigh the potential environmental impacts, derived or associated with the production of electricity from wind energy in Ecuador. The purpose or projection is to encourage to the Ministry of Energy and NonRenewable Natural Resources, as well as the Agency for the Regulation and Control of Energy and Non-Renewable Natural Resources - ARC, of Ecuador, to replicate what concerns the rest of the technologies that make up the Ecuadorian energy mix, in order to be able to compare them and make the corresponding decisions regarding energy sustainability.

In order to achieve this objective, the Life Cycle Analysis [8] will be used, which is no more than a methodological tool that allows measuring the environmental impact of a product, process or system throughout a part or all of its life cycle, where the main characteristic of this tool is its holistic approach, that is to say, that it is based on the idea that all the properties of a product, process or system cannot be determined or explained only individually by the parts that compose it, being necessary the total integration of all the aspects that participate; hence, the concept of taking into account the entire life cycle; from there, the concept of taking into account the entire life cycle of a product, process or system.

To fully define the scope of this study, it must be specified: a) the environmental impacts to be considered; b) the wind turbine to be studied; that is, specify its brand, model, type and capacity; c) the limits of the system to be analyzed; and, d) the functional 
unit. In this way, the Environmental Impact Categories to be taken into account are showed in Figure 2. This study is a cradle-to-grave LCA, assessing the potential environmental impacts associated with electricity generated from a $16.5 \mathrm{MW}$ onshore wind farm comprised of eleven Goldwind GW70 1.5 MW wind turbines over its full life cycle. Regarding the lifetime of the wind farm, it will be considered to be 20 years. This corresponds to the design lifetime of the Goldwind GW70 1.5 MW wind turbine and applies to all components of the wind farm except for certain spare parts. This lifetime value is that set out in the International Standard IEC61400-1: Wind Turbines - Part 1: Design requirements [9].

In relation to the functional unit, this corresponds to the parameter that quantifies the action of the product or system when the associated function is executed. Given that the function of wind turbines is electricity production, and given that these machines are manufactured with different characteristics, the Functional Unit to be used in this LCA is the $\mathrm{kWh}$ of energy delivered to the grid. Basically, it is the unit that will be referenced from the environmental loads of the inventory to the final results of the life cycle analysis.

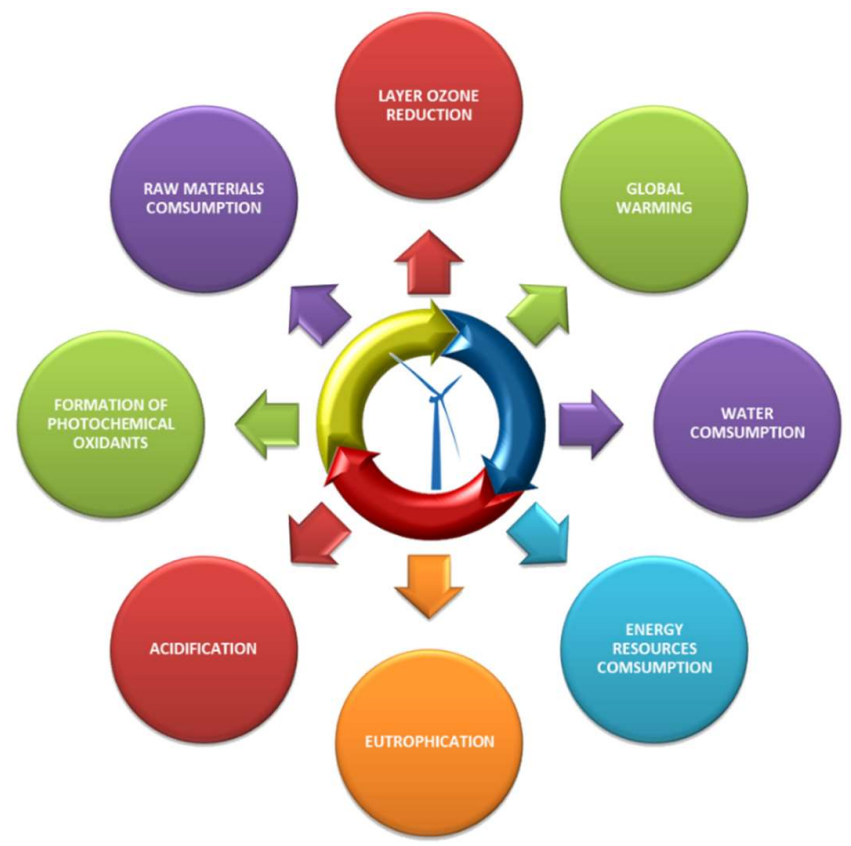

Figure 2. Environmental Impact Categories.

In this way, the scope of the study is perfectly formulated, as it has been decided to consider only the Environmental Impact Category of Global Warming, specifically $\mathrm{CO}_{2}$ emissions and Water Consumption, involved in the complete life cycle of wind technology and Accumulated Energy Demand, as a plus to support the sustainability of this technology.

\section{Background}

Sankey's scheme shown in Figure 3, represents the Energy Structure of Ecuador 2019; which relates primary and final energy in Ecuador in the aforementioned year, where primary energy production reached $223 \mathrm{MBOE}$; that is, 32.59 Mtoe, while energy demand reached $94 \mathrm{MBOE}$; that is, 13.74 Mtoe. In 2019 the predominant energy source in Ecuador's primary energy matrix was oil. Of the total produced, $86.9 \%$ corresponds to oil, $4.4 \%$ to natural gas, and $8.7 \%$ to energy from renewable sources (hydroelectric power, firewood, cane products, wind, photovoltaic energy and biogas). 


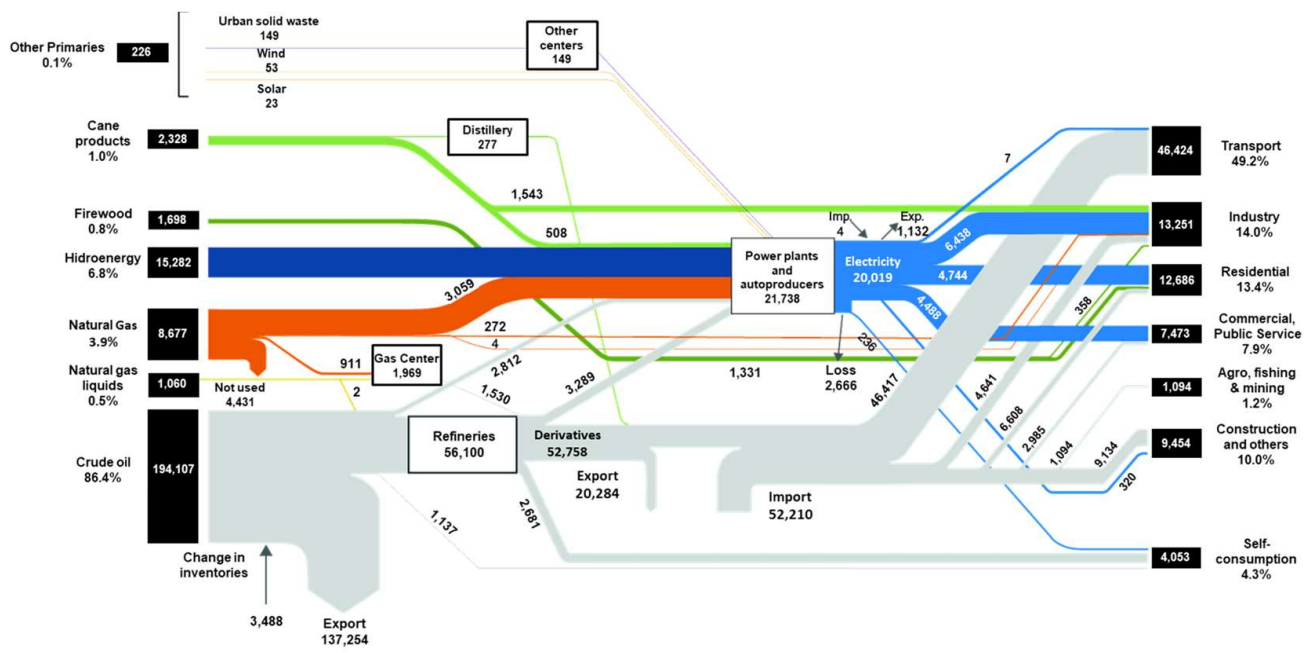

Figure 3. Energy Structure of Ecuador 2019. Credit: IIGE - Ecuador [10].

Electricity in Ecuador comes from both renewable and non-renewable sources. That which is produced by renewable sources is composed of hydroelectric, photovoltaic, wind and thermoelectric plants that consume biomass and biogas; while non-renewable types use fossil fuels and are classified as turbogas, turbo-steam and internal combustion engines (ICM). In 2019, renewable energy sources represented almost $65 \%$ of the effective power at national level.

Table 1. Nominal and effective power by type of source. Credit: ARC [11].

\begin{tabular}{|c|c|c|c|c|c|}
\hline \multirow[b]{2}{*}{ Source Type } & \multirow[b]{2}{*}{ Plant Type } & \multirow[b]{2}{*}{ Unit Type } & \multirow{2}{*}{$\begin{array}{l}\text { Rated Power } \\
\text { (MW) }\end{array}$} & \multicolumn{2}{|c|}{ Effective Power } \\
\hline & & & & (MW) & $\%$ \\
\hline \multirow{5}{*}{ Renewable } & Hydroelectric & Hydroelectric & $5,076.40$ & $5,046.63$ & $62.51 \%$ \\
\hline & Biomass & Turbo-steam & 144.30 & 136.40 & $1.69 \%$ \\
\hline & Photovoltaic & Photovoltaic & 27.63 & 26.74 & $0.33 \%$ \\
\hline & Wind & Eolic & 21.15 & 21.15 & $0.26 \%$ \\
\hline & Biogas & ICM & 7.26 & 6.50 & $0.08 \%$ \\
\hline \multicolumn{3}{|l|}{ Renewable Total } & $5,276.74$ & $5,237.42$ & $64.88 \%$ \\
\hline \multirow{3}{*}{ Non-renewable } & \multirow{3}{*}{ Thermoelectric } & ICM & $2,024.80$ & $1,628.34$ & $20.17 \%$ \\
\hline & & Turbogas & 921.85 & 775.55 & $9.61 \%$ \\
\hline & & Turbo-steam & 461.63 & 431.50 & $5.35 \%$ \\
\hline \multicolumn{3}{|c|}{ Non-renewable Total } & $3,408.28$ & $2,835.39$ & $35.12 \%$ \\
\hline \multicolumn{3}{|c|}{ Total } & $8,685.02$ & $8,072.81$ & $100.00 \%$ \\
\hline
\end{tabular}

Ecuador's first onshore wind farm of 2.4 MW, located on the island of San Cristóbal in the Galapagos Archipelago, was inaugurated in October 2007, comprised of three Made AE-59 $800 \mathrm{~kW}$ wind turbines. In 2014, the second onshore wind farm was incorporated, with $2.25 \mathrm{MW}$, projected to reach $12 \mathrm{MW}$ and initially comprised of three $750 \mathrm{~kW}$ wind turbines, located on Baltra Island in the Galapagos Archipelago.

The first onshore wind farm built in Ecuadorian continental territory is the Villonaco Wind Central - CEV of $16.5 \mathrm{MW}$, located in the province of Loja, $14 \mathrm{~km}$ from its capital; specifically built along the summit line of Villonaco hill, at an approximate height of 2,720 m.a.s.l., conformed by eleven Goldwind GW70 1.5 MW wind turbines. At present, an onshore wind farm of 51.2 MW is being built, comprised of sixteen DongFang D3200-155 3.2 MW wind turbines [12], located in the area known as Minas de Huascachaca in the province of Loja. 
The single-line diagram of CEV is shown in Figure 4, where a Pad-Mounted type transformer is installed in each wind turbine, raising the voltage from $620 \mathrm{~V}$ to $34.5 \mathrm{kV}$; then, in the Villonaco electric substation the voltage is raised from $35 \mathrm{kV}$ to $69 \mathrm{kV}$ with a 25 MVA power transformer from which the energy is delivered to the National Interconnected System - NIS through the Loja substation.

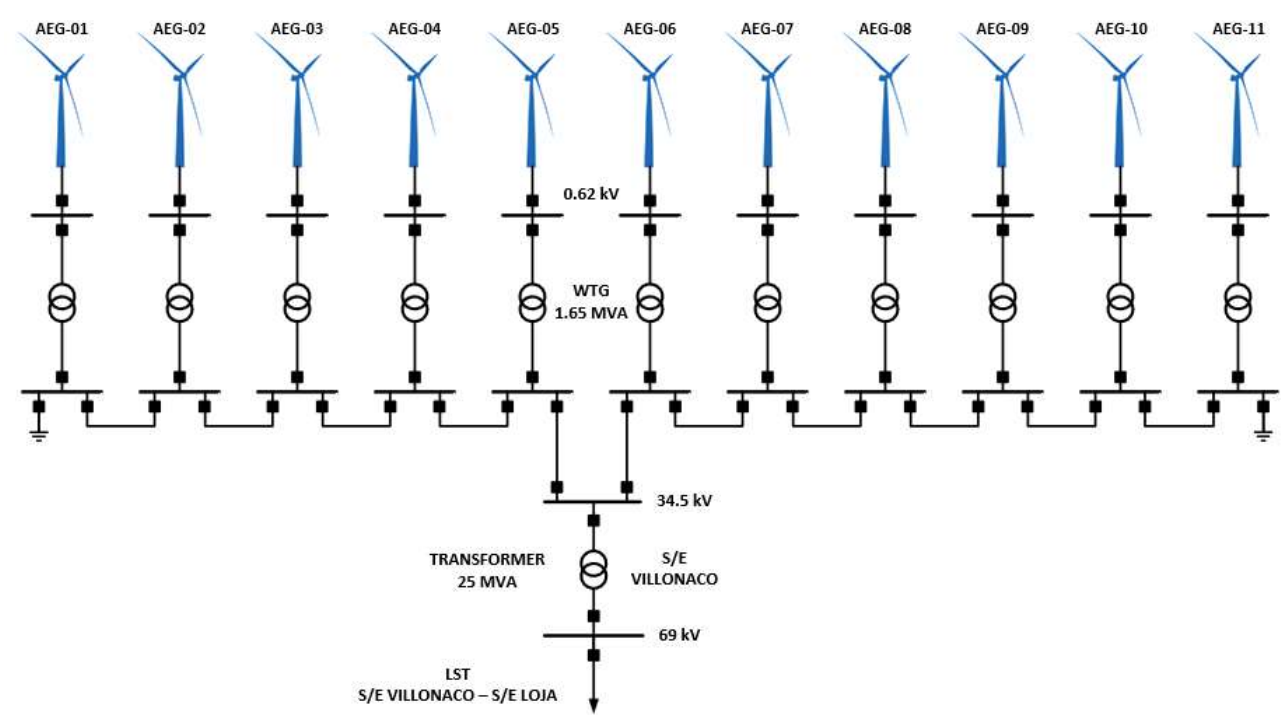

Figure 4. Single-line diagram of the Villonaco Wind Central - CEV.

Although wind technology has a small share, both in terms of electricity generation and installed capacity, it has been determined that Ecuador has a Total Gross Available Wind Energy Potential of 1.67 GW, and a Feasible Wind Energy Potential in the short term of $0.88 \mathrm{GW}$, simultaneously with an associated energy production of $2.87 \mathrm{TWh} /$ year and $1.52 \mathrm{TWh} /$ year respectively as shown in Table 2.

Table 2. Wind energy potential in Ecuador. Data compiled from [13].

\begin{tabular}{|c|c|c|c|c|}
\cline { 2 - 5 } \multicolumn{1}{c|}{} & Wind $[\mathrm{m} / \mathrm{s}]$ & Area $\left[\mathrm{km}^{2}\right]$ & Power $[M W]$ & Energy [MWh] \\
\hline \multirow{4}{*}{$\begin{array}{c}\text { Gross Available } \\
\text { Wind Energy } \\
\text { Potential }\end{array}$} & $>7.0$ & 556.99 & $1,670.96$ & $2,868.98$ \\
\cline { 2 - 5 } & $>7.5$ & 309.96 & 929.87 & $1,995.68$ \\
\cline { 2 - 5 } & $>8.0$ & 166.54 & 499.61 & $1,286.72$ \\
\cline { 2 - 5 } & $>8.5$ & 91.59 & 274.76 & 825.57 \\
\hline \multirow{4}{*}{$\begin{array}{c}\text { Feasible Wind } \\
\text { Energy Potencial }\end{array}$} & $>7.0$ & 294.74 & 884.22 & $1,518.17$ \\
\cline { 2 - 5 } & $>7.5$ & 158.50 & 475.51 & 638.47 \\
\cline { 2 - 5 } & $>8.0$ & 82.64 & 247.91 & 408.81 \\
\hline
\end{tabular}

The Villonaco's II and III projects will be granted as a concession through a public bidding process, where the condition is that it has a minimum combined installed capacity of $110 \mathrm{MW}$. Both projects will enjoy the same microclimate of Villonaco I project, which is characterized by its optimal capacity factor of $53.7 \%$ and an average wind speed of 12.4 $\mathrm{m} / \mathrm{s}$. 


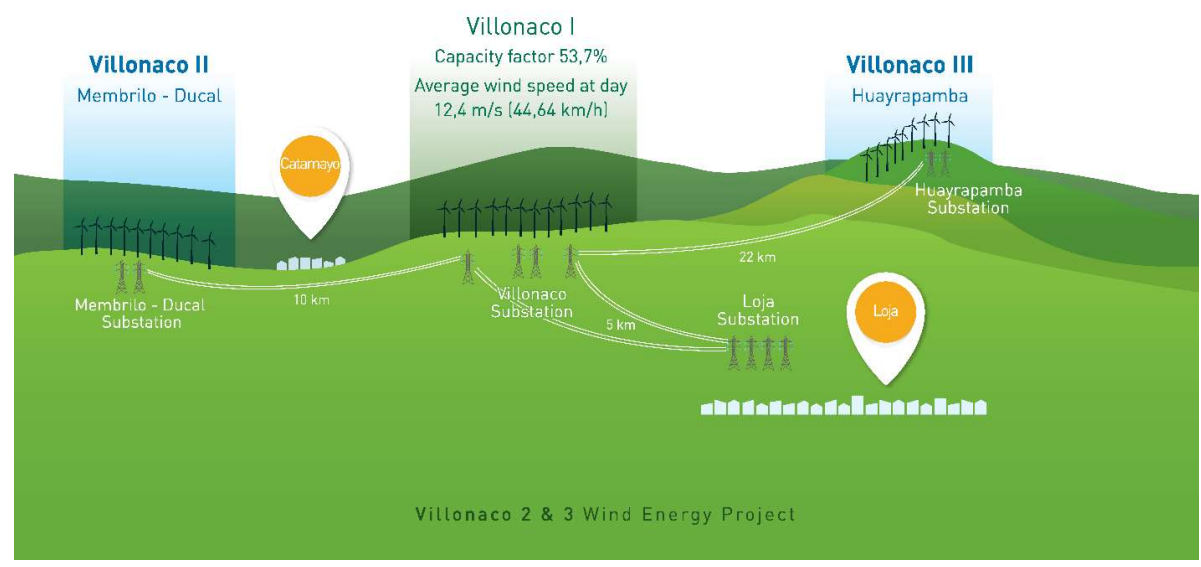

Figure 5. Geographic location of Villonaco II \& III Wind Farm Projects [14].

\section{Technical description}

"The Goldwind GW70/1500 wind turbine is a gearless wind energy converter and is equipped with a three-blade rotor, pitch control with a rated output of $1,500 \mathrm{~kW}$. This converter generates electric current that is fed directly into a step-up transformer and ultimately the public grid. Optimum aerodynamic rotor efficiency, at every wind speed, is achieved by using variable speed technology" [15]. A summary of the most important features and a schematic view with all the parts that compose this wind turbine are shown in Table 3 and Figure 6, respectively. This section may be divided by subheadings. It should provide a concise and precise description of the experimental results, their interpretation, as well as the experimental conclusions that can be drawn.

Table 3. Features of Goldwind GW70/1500 wind turbine. Credit: Goldwind company [15].

\begin{tabular}{|c|c|}
\hline Highly efficient multipole generator & Blade pitch system and safety system \\
\hline $\begin{array}{l}\text { Direct coupling of the multipole generator to the rotor } \\
\text { - } \quad \text { No gearbox required } \\
\text { - } \quad \text { Practical application of advanced technologies }\end{array}$ & \multirow{2}{*}{$\begin{array}{ll}\text { Blade pitch system with tooth belts } \\
-\quad \text { Lubrication not required } \\
\text { - } \quad \text { Minimum play in blade drive tracks } \\
\text { - } \quad \text { Minimum wear } \\
\text { - } & \text { Maintenance free }\end{array}$} \\
\hline $\begin{array}{l}\text { Synchronous generator with permanent magnet excitation } \\
\text { - } \quad \text { High efficiency, particularly at partial load } \\
\text { - } \quad \text { No energy losses because of an external excitation } \\
\text { - } \quad \text { No slip rings for external excitation needed }\end{array}$ & \\
\hline $\begin{array}{l}\text { External runner concept } \\
\text { - Compact design, small generator diameter }\end{array}$ & \multirow{2}{*}{$\begin{array}{l}\text { Double-layer capacitor for emergency re-pitching } \\
\text { - } \quad \text { No heavy lead-gel accumulators required } \\
\text { - } \quad \text { Brush-less pitch motor } \\
\text { - } \quad \text { Increased lifetime } \\
\text { - } \quad \text { Maintenance free }\end{array}$} \\
\hline $\begin{array}{l}\text { Passive air-cooling system } \\
\text { - } \quad \text { Highly efficient cooling without any additional energy }\end{array}$ & \\
\hline
\end{tabular}

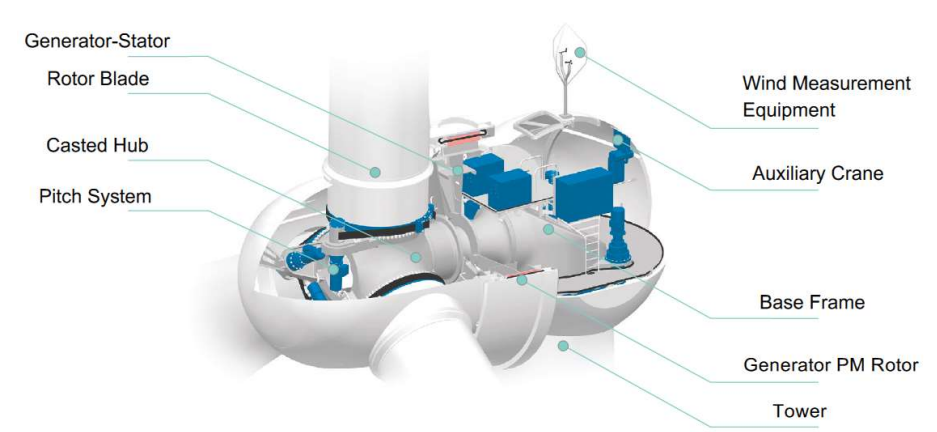

Figure 6. Schematic view of GW70/1500 wind turbine. Courtesy: Goldwind company [16].

\section{Analysis Methodology}


For the LCA, a series of simulations will be carried out using the SimaPro software, recreating each and every one of the processes required to produce $1 \mathrm{kWh}$ [17] of electricity from wind technology in Ecuador. In general, the stages that make up an LCA are Supply of raw materials and components, Manufacturing, Distribution, Assembly and installation, Operation, Maintenance, and Dismantling and end-of-life. In order to facilitate the understanding of the results of this study, the seven stages have been grouped into five, as described below:

1. Construction: which includes the supply of raw materials, their processing to produce the materials necessary for the manufacture of the components required for the different elements that make up the wind farm and for the subsequent manufacture of each of the components of the wind turbine, including the conductors required for electrical connection.

2. Distribution: in which both, the transport of the raw materials for the manufacture of the wind turbines and the transport to the site are included, as well as all the transport required during the operation time of the wind farm.

3. Assembly or erection: the same that considers all the work that is required to erect and install the wind turbines.

4. Operation and Maintenance: referring to the maintenance of the wind farm, considering the necessary preventive and corrective maintenance, basically concerning oil changes and lubrication.

5. Dismantling and end-of-life: includes the dismantling of the wind farm, as well as the transport for the elimination of residues and/or the recycling of the components that can be used.

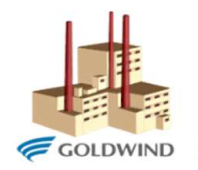
CONSTRUCTION

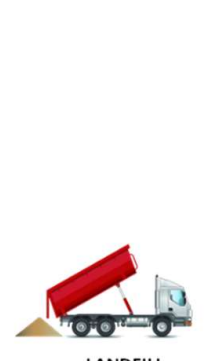

LANDFILL
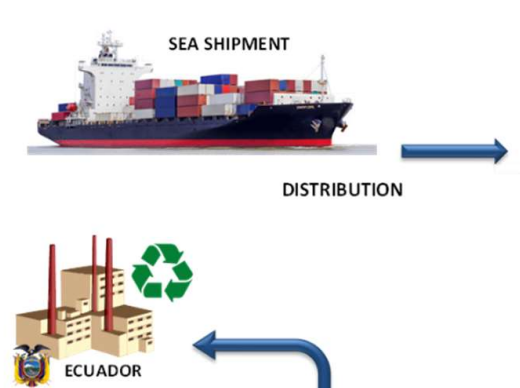
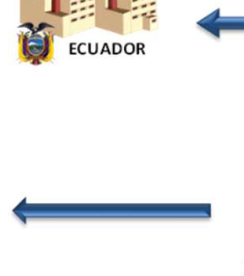
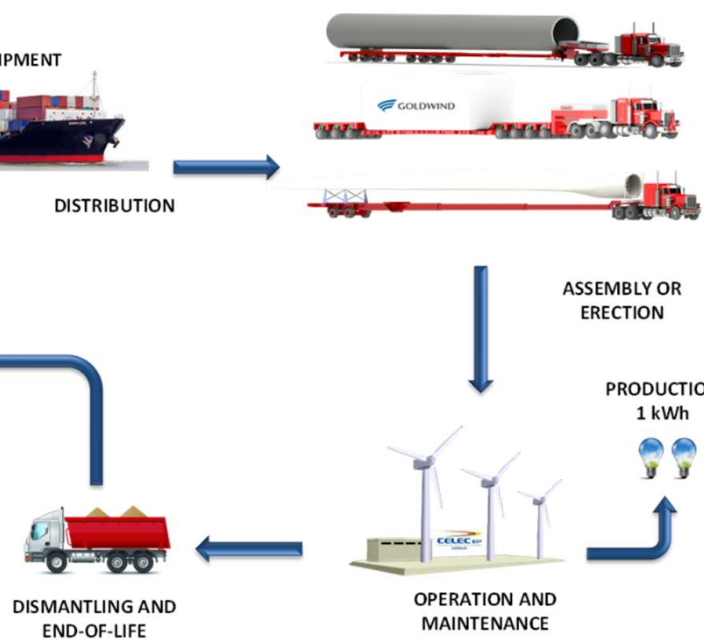

Figure 7. Life cycle stages for a Goldwind wind turbine.

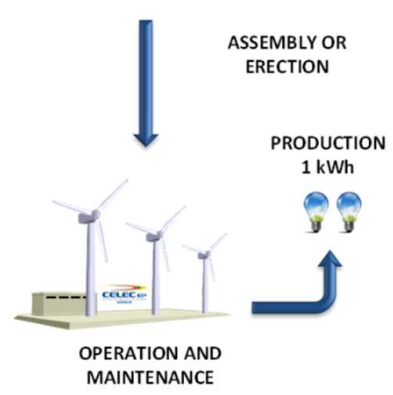

In order to determine the impact contribution to climate change, a parameter used is the so-called Carbon Footprint, which allows to represent the volume of greenhouse gas (GHG) emissions related to a company, event, activity or the life cycle of a product, system or service. However, the right terminology, or at least appropriate, should be carbon footprint or $\mathrm{CO}_{2}$ equivalent emissions, since it does not only weight carbon emissions; however, in practice and commonly, the term carbon is simply used.

To determine the carbon footprint of the GW70 1.5MW wind turbine, it has used the European impact analysis method "ILCD 2011 Midpoint+ v1.10 / EC-JRC Global, equal weighting" [18], specifying that our analysis will focus exclusively on the category of climate change, as this is the only category of interest for determining the amount of $\mathrm{CO}_{2}$ equivalent generated. Given that for this calculation methodology, the normalization, weighting and single score formats do not provide relevant information in this analysis, 
it was decided to dispense with them and consider that the information obtained should be presented in the characterization format. A similar situation occurs for the analysis of the water footprint $[19,20]$, where the impact methodology "Berger et al, 2014, Water Scarcity, v1.0" [21] will be used for its determination.

\section{Development of the study}

\subsection{Construction stage}

Although the present LCA was declared to be carried out "from cradle to grave" [22]; and, not being able to count on specific information regarding the raw materials as well as those related to their processing, with the purpose of elaborating the different inputs used to manufacture each of the components of the wind turbine under study, the LCA will begin directly with the manufacturing phase of said components, supported by the information provided by the Goldwind company. Regarding the production processes of the input materials used to manufacture the components of the wind turbine, those used in the ECOINVENT v3.7.1 database [23] have been taken, considering the respective modifications to the processes and adapting them, of course, to the corresponding energy mix; taking into account that the wind turbines were entirely manufactured in Beijing, China, which is where the factory of such equipment is located.

To be precise, two types of processes are available in SimaPro, namely the market process and the transformation process. The fundamental difference between the two is that in the market process, transport related emissions are already included, whereas in the transformation process, they are not considered. This is an important point to consider when carrying out the simulation. Thus, the inventory of materials to be entered for the construction process of the referred wind turbine is detailed in Table 4, obtained from the primary information provided by Goldwind and complemented with the ECOINVENT database.

Table 4. Inputs from the Technosphere; supplies materials for wind turbine construction.

\begin{tabular}{|c|c|c|c|}
\hline Material & Inputs in SimaPro & Quantity & Components \\
\hline $\begin{array}{l}\text { Aluminum } \\
\text { cast alloy }\end{array}$ & Aluminum, cast alloy $\{G L O\} \mid$ market for $\mid A P O S, U$ & 0.54 ton & \multirow{2}{*}{$\begin{array}{c}\text { Grid connection, } \\
\text { transformer, auxiliary crane, } \\
\text { and blade pitch system. }\end{array}$} \\
\hline $\begin{array}{l}\text { Aluminum } \\
\text { wrought alloy }\end{array}$ & Aluminum, wrought alloy $\{G L O\} \mid$ market for $\mid A P O S, U$ & 1.14 ton & \\
\hline Cast iron & Cast iron $\{G L O\} \mid$ market for $\mid A P O S, U$ & 20.61 ton & $\begin{array}{l}\text { Hub, nacelle and } \\
\text { foundation. }\end{array}$ \\
\hline $\begin{array}{l}\text { Reinforcing } \\
\text { steel }\end{array}$ & Reinforcing steel $\{G L O\} \mid$ market for $\mid A P O S, U$ & 46.90 ton & $\begin{array}{l}\text { Nacelle, axis and } \\
\text { foundation. }\end{array}$ \\
\hline Copper & Copper $\{G L O\} \mid$ market for $\mid$ APOS, $U$ & 2.81 ton & $\begin{array}{l}\text { Cables, transformer } \\
\text { and generator. }\end{array}$ \\
\hline Concrete & $\begin{array}{l}\text { Concrete, high exacting requirements }\{\text { RoW }\} \mid \text { market for } \\
\mid \text { APOS, } U\end{array}$ & $348.05 \mathrm{~m}^{3}$ & Foundation. \\
\hline $\begin{array}{c}\text { Steel, } \\
\text { low-allowed }\end{array}$ & Steel, low-alloyed $\{G L O\} \mid$ market for $\mid$ APOS, $U$ & 195.43 ton & $\begin{array}{l}\text { Tower, crane system and } \\
\text { Yawing system. }\end{array}$ \\
\hline Epoxy resin & Epoxy resin, liquid $\{G L O\} \mid$ market for $\mid A P O S, U$ & 9.43 ton & \multirow{3}{*}{$\begin{array}{l}\text { Blades, cone and } \\
\text { nacelle cover }\end{array}$} \\
\hline Glass fibre & $\begin{array}{l}\text { Glass fibre reinforced plastic, polyamide, injection } \\
\text { moulded }\{G L O\} \mid \text { market for } \mid A P O S, U\end{array}$ & 14.14 ton & \\
\hline $\begin{array}{l}\text { Polyethylene } \\
\text { high density }\end{array}$ & $\begin{array}{l}\text { Polyethylene, high density, granulate }\{G L O\} \mid \text { market for } \\
\mid \text { APOS, } U\end{array}$ & 3.08 ton & \\
\hline $\begin{array}{l}\text { Sheet rolling } \\
\text { aluminum }\end{array}$ & Sheet rolling, aluminum $\{G L O\} \mid$ market for $\mid A P O S, U$ & 1.67 ton & Yawing system. \\
\hline Welding & Welding, arc, steel $\{G L O\} \mid$ market for $\mid A P O S, U$ & $294.92 m$ & $\begin{array}{c}\text { For welding each steel } \\
\text { plate, rolled sections } \\
\text { together to form the tower. } \\
\text { Estimated value. }\end{array}$ \\
\hline Zinc & Zinc $\{G L O\} \mid$ market for $\mid$ APOS, $U$ & $202.26 \mathrm{~kg}$ & $\begin{array}{l}\text { For the preparation of the } \\
\text { zinc coating. }\end{array}$ \\
\hline Zinc coat & Zinc coat, pieces $\{G L O\} \mid$ market for | APOS, $U$ & $976.11 \mathrm{~m}^{2}$ & $\begin{array}{c}\text { Estimated surface to be } \\
\text { zinc coated. With a } \\
\text { diameter of } 4 \mathrm{~m} \text { and a tower } \\
\text { height of } 78 \mathrm{~m} \text {, respectively. }\end{array}$ \\
\hline
\end{tabular}


The table above details the type of material, the input process in SimaPro, the amount of each material needed to build the wind turbine, as well as a detail of the components where these materials are present. In addition to the inventory detailed in Table 4, everything concerning electronic devices necessary for the subsequent automation and control of the wind turbine is included, as well as the amount of electrical energy demanded during the construction process of the wind turbine unit, a value that has been taken from the ECOINVENT DB. This would result in five additional inputs as shown in Table 5.

Table 5. Inputs provided by SimaPro for wind turbine construction.

\begin{tabular}{|l|c|c|}
\hline \multicolumn{1}{|c|}{ Inputs in SimaPro } & Quantity & Unit \\
\hline Electronics, for control units $\{$ GLO\}| market for | APOS, $U$ & 438.40 & $\mathrm{~kg}$ \\
\hline Excavation, hydraulic digger $\{$ GLO\}| market for | APOS, $U$ & 348.72 & $\mathrm{~m}^{3}$ \\
\hline Road $\{\mathrm{CH}\} \mid$ market for road | APOS, $U$ & 67.09 & $\mathrm{my}$ \\
\hline Road $\{$ RoW\}| market for road | APOS, U & $7,903.75$ & $\mathrm{my}$ \\
\hline Electricity, medium voltage $\{$ RoW\}| market for | APOS, $U$ & $143,773.34$ & $\mathrm{kWh}$ \\
\hline
\end{tabular}

It should be noted that, for this stage of construction, it has been considered the construction of an access road to the site where the wind farm is located, also taking into account the excavation of the land by means of a hydraulic digger that will allow the laying of the foundations on which the bases of each of the wind turbines will be placed.

Thus, the combination of these inputs, those indicated in Tables 4 and 5, which consider the information provided by the Goldwind company with the data collected by the ECOINVENT database, constitutes the wind turbine construction process, represented by Wind turbine, $2 M W$, onshore $\{G L O\} \mid$ construction | APOS, U.
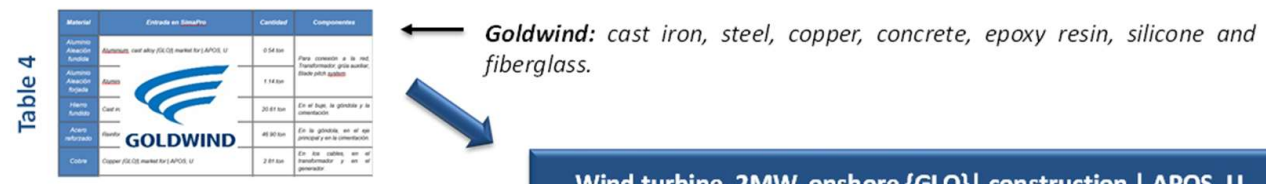

Wind turbine, 2MW, onshore $\{$ GLO $\}$ | construction | APOS, U.
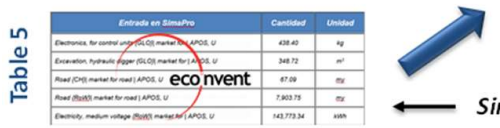

SimaPro: EC's, hydraulic digger, access road to the site and electricity.

Figure 8. Schematic view of construction stage creation in SimaPro.

\subsection{Transport stage}

At this stage, in order to optimize the simulation in SimaPro, three types of transportation must be considered: a) transportation associated with the production of materials, b) transportation from the manufacturing centers to the wind farm, and c) transportation during the operation of the wind farm.

\subsubsection{Transportation associated with the production of materials}

Unlike what is done in other countries, such as Spain, for example, for the Villonaco wind farm in Loja, Ecuador, the tower of each wind turbine was purchased and not manufactured on site, with three cylindrical sections, whose welding process was applied in the factory, being assembled by means of a complex bolting system and having the dimensions shown in the following table. 
Table 6. Dimensions and weights of each wind turbine tower section.

\begin{tabular}{|c|c|c|c|c|}
\hline GW70/1500 & Section 1 & Section 2 & Section 3 & Total \\
\hline Longitude $[\mathrm{m}]$ & 15 & 22.8 & 25 & 62.8 \\
\hline Diameter $[\mathrm{m}]$ & 4.80 & 3.45 & 3.00 & -- \\
\hline Weight $[$ ton] & 40.38 & 36.12 & 25.76 & 102.26 \\
\hline
\end{tabular}

Due to the fact that not everything concerning the raw materials and their respective transportation for the production of the materials with which the wind turbine will be built is known, the decision was made to keep the information predefined by the ECOINVENT database, assuming that these materials have been obtained in Asia. In this way, and with the purpose of producing $1 \mathrm{~kg}$ of each of the materials, the main transport inputs in the "market" processes of SimaPro are presented, which are collected and grouped in Table 7.

Table 7. Transport inputs associated with the construction of the wind turbine.

\begin{tabular}{|c|c|c|}
\hline Materials & Inputs in SimaPro & $\begin{array}{c}\text { Traffic unit } \\
\text { [ton-km] }\end{array}$ \\
\hline \multirow{2}{*}{$\begin{array}{l}\text { Aluminum } \\
\text { Cast alloy }\end{array}$} & Transport, freight train $\{G L O\} \mid$ market group for $\mid A P O S, U$ & 0.3448 \\
\hline & Transport, freight, lorry, unspecified $\{G L O\} \mid$ market for $\mid A P O S, U$ & 0.3614 \\
\hline \multirow{2}{*}{$\begin{array}{l}\text { Aluminum } \\
\text { Wrought alloy }\end{array}$} & Transport, freight train $\{G L O\} \mid$ market group for $\mid A P O S, U$ & 0.3448 \\
\hline & Transport, freight, lorry, unspecified $\{G L O\} \mid$ market for $\mid A P O S, U$ & 0.3614 \\
\hline \multirow{2}{*}{ Cast iron } & Transport, freight train $\{G L O\} \mid$ market group for $\mid A P O S, U$ & 0.1903 \\
\hline & Transport, freight, lorry, unspecified $\{G L O\} \mid$ market for $\mid A P O S, U$ & 0.2065 \\
\hline \multirow{2}{*}{ Reinforced steel } & Transport, freight train $\{G L O\} \mid$ market group for $\mid A P O S, U$ & 0.1903 \\
\hline & Transport, freight, lorry, unspecified $\{G L O\} \mid$ market for $\mid A P O S, U$ & 0.2065 \\
\hline \multirow{2}{*}{ Copper } & Transport, freight train $\{G L O\} \mid$ market group for $\mid A P O S, U$ & 0.3861 \\
\hline & Transport, freight, lorry, unspecified $\{G L O\} \mid$ market for $\mid A P O S, U$ & 0.1739 \\
\hline \multirow{2}{*}{ Concrete } & Transport, freight train $\{G L O\} \mid$ market group for $\mid A P O S, U$ & 13.394 \\
\hline & Transport, freight, lorry, unspecified $\{G L O\} \mid$ market for $\mid A P O S, U$ & 142.252 \\
\hline \multirow{2}{*}{ Low-alloy steel } & Transport, freight train $\{G L O\} \mid$ market group for $\mid A P O S, U$ & 0.1903 \\
\hline & Transport, freight, lorry, unspecified $\{G L O\} \mid$ market for $\mid A P O S, U$ & 0.2065 \\
\hline \multirow{2}{*}{ Epoxy resin } & Transport, freight train $\{G L O\} \mid$ market group for $\mid A P O S, U$ & 0.2887 \\
\hline & Transport, freight, lorry, unspecified $\{G L O\} \mid$ market for $\mid A P O S, U$ & 0.4504 \\
\hline \multirow{2}{*}{ Glass fibre } & Transport, freight, light commercial vehicle $\{G L O\} \mid$ market for | APOS, $U$ & 0.0246 \\
\hline & Transport, freight, lorry, unspecified $\{G L O\} \mid$ market for $\mid A P O S, U$ & 0.3857 \\
\hline \multirow{2}{*}{$\begin{array}{c}\text { Polyethylene high } \\
\text { density }\end{array}$} & Transport, freight train $\{G L O\} \mid$ market group for $\mid A P O S, U$ & 0.2887 \\
\hline & Transport, freight, lorry, unspecified $\{G L O\} \mid$ market for $\mid A P O S, U$ & 0.4504 \\
\hline
\end{tabular}

\subsubsection{Transportation from the manufacturing sites to the wind farm}

The next transportation stage on which this LCA will focus will be related to the transportation of the different parts that make up the wind turbine from the manufacturing centers to the site where the wind farm will be erected.

In this case, the different components of the turbine were manufactured in the Industrial Park of Goldwind, manufacturer of the wind turbine model to which the LCA is being applied, located in the Technological Development Zone of Beijing, China, where the subsidiary "Beijing Goldwind Science \& Creation Windpower Equipment Co., Ltd." operates, being shipped from there to Loja, Ecuador, where the Villonaco Wind Farm will be erected. 
In order to determine the traffic units, i.e., the tons transported per travel distance [ton kilometers] associated with each component, the distances that would be covered in the transportation of the components and the different types of transportation involved had to be obtained. Each component will be transported by road from the city of BeijingChina to the Port of Tianjin-China; from the latter, by sea, to Puerto Bolivar-Ecuador; and from there, along the old Catamayo-Loja highway, to the site where the Villonaco Wind Farm is located. For this purpose, Table 8 lists and indicates the weight of each component of each wind turbine.

Table 8. Weight of each wind turbine component [15].

\begin{tabular}{|l|c|}
\multicolumn{1}{|c|}{$\begin{array}{c}\text { Components } \\
\text { GW70/1500 }\end{array}$} & Weight [ton] \\
\hline Nacelle & 12.77 \\
\hline Hub & 14.19 \\
\hline Blades & $5.72 \times 3=17.16$ \\
\hline Tower (3 sections) & 102.26 \\
\hline Generator and others & 45.90 \\
\hline \multicolumn{2}{|c|}{$\begin{array}{c}\text { Wind turbine } \\
\text { TOTAL }\end{array}$} \\
\hline \multicolumn{2}{|c|}{} \\
\hline
\end{tabular}

In order to obtain the distances by sea and land routes; that will have to be transported each of the components of each of the wind turbines that make up the Villonaco Wind Farm, we will use the help of the Searates portal.

Table 9. Distance for sea and land transportation.

\begin{tabular}{|c|c|c|c|}
\hline Origin & Destination & Distance $[\mathrm{km}]$ & Transportation by \\
\hline Beijing & Tianjin & 172.43 & Land \\
\hline Tianjin & Puerto Bolivar & $16,751.92$ & Sea \\
\hline Puerto Bolívar & Villonaco - Loja & 236.76 & Land \\
\hline
\end{tabular}

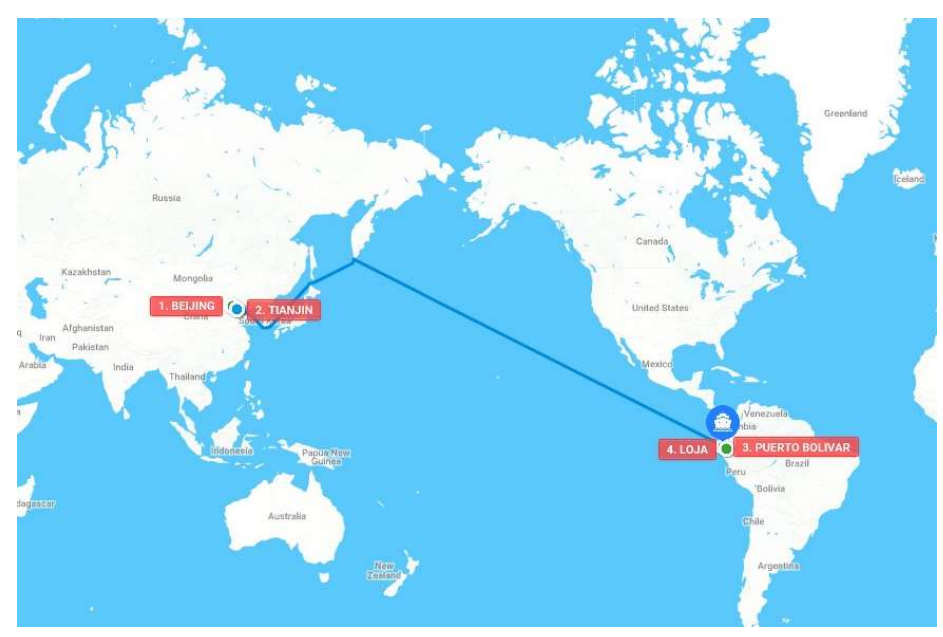

Figure 9. Beijing - Tianjin - Puerto Bolivar - Loja Route. Source: Searates

Finally, from the weight of each component of each wind turbine and the distance that has been obtained through Searates and that was detailed in Table 9, the tons per 
kilometer will be determined by direct multiplication, as SimaPro inputs, related to this stage; which are detailed below.

Table 10. SimaPro entries for transportation from manufacturing sites to the wind farm.

\begin{tabular}{|c|c|c|}
\hline Component & Inputs in SimaPro & $\begin{array}{c}\text { Traffic unit } \\
\text { [ton-km] }\end{array}$ \\
\hline \multirow{2}{*}{ Nacelle } & Transport, freight, sea, transoceanic ship $\{G L O\} \mid$ market for $\mid A P O S, U$ & $213,838.26$ \\
\hline & Transport, freight, lorry >32 metric ton, EURO4 \{GLO\}| market for $\mid A P O S, U$ & $5,223.31$ \\
\hline \multirow{2}{*}{ Hub } & Transport, freight, sea, transoceanic ship $\{G L O\} \mid$ market for $\mid A P O S, U$ & $237,709.74$ \\
\hline & Transport, freight, lorry >32 metric ton, EURO4 $\{G L O\} \mid$ market for $\mid A P O S, U$ & $5,806.41$ \\
\hline \multirow{2}{*}{ Generator } & Transport, freight, sea, transoceanic ship $\{G L O\} \mid$ market for $\mid A P O S, U$ & $768,913.13$ \\
\hline & Transport, freight, lorry >32 metric ton, EURO4 $\{G L O\} \mid$ market for | APOS, U & $18,781.82$ \\
\hline \multirow{2}{*}{$\begin{array}{c}\text { Tower } \\
\text { Section } 1\end{array}$} & Transport, freight, sea, transoceanic ship $\{G L O\} \mid$ market for | APOS, $U$ & $676,392.27$ \\
\hline & Transport, freight, lorry >32 metric ton, EURO4 \{GLO\}| market for $\mid A P O S, U$ & $16,521.86$ \\
\hline \multirow{2}{*}{$\begin{array}{c}\text { Tower } \\
\text { Section } 2\end{array}$} & Transport, freight, sea, transoceanic ship $\{G L O\} \mid$ market for | APOS, $U$ & $605,062.60$ \\
\hline & Transport, freight, lorry >32 metric ton, EURO4 $\{G L O\} \mid$ market for $\mid A P O S, U$ & $14,779.53$ \\
\hline \multirow{2}{*}{$\begin{array}{c}\text { Tower } \\
\text { Section } 3\end{array}$} & Transport, freight, sea, transoceanic ship $\{G L O\} \mid$ market for | APOS, $U$ & $431,462.45$ \\
\hline & Transport, freight, lorry >32 metric ton, EURO4 $\{G L O\} \mid$ market for $\mid A P O S, U$ & $10,539.10$ \\
\hline \multirow{2}{*}{ Blade 1} & Transport, freight, sea, transoceanic ship $\{G L O\} \mid$ market for $\mid A P O S, U$ & $95,820.98$ \\
\hline & Transport, freight, lorry 16-32 metric ton, EURO4 \{GLO\}| market for $\mid A P O S, U$ & $2,340.57$ \\
\hline \multirow{2}{*}{ Blade 2} & Transport, freight, sea, transoceanic ship $\{G L O\} \mid$ market for $\mid A P O S, U$ & $95,820.98$ \\
\hline & Transport, freight, lorry 16-32 metric ton, EURO4 \{GLO\}| market for |APOS, $U$ & $2,340.57$ \\
\hline \multirow{2}{*}{ Blade 3} & Transport, freight, sea, transoceanic ship $\{G L O\} \mid$ market for | APOS, $U$ & $95,820.98$ \\
\hline & Transport, freight, lorry 16-32 metric ton, EURO4 \{GLO\}| market for $\mid A P O S, U$ & $2,340.57$ \\
\hline
\end{tabular}

All these transport sub-processes added to the wind turbine construction process are defined by Wind turbine, $2 \mathrm{MW}$, onshore $\{\mathrm{GLO}\} \mid$ construction I APOS, $U$, and constitute -for the simulation of the SimaPro software tool- the "market" type process named: Wind turbine, 2MW, onshore $\{$ GLO $\}$ | market for I APOS, U.

\subsubsection{Transportation during the operation of the wind farm}

Since it was not possible to obtain specific data on transport during wind farm operation, the information provided by the ECOINVENT database in SimaPro had to be used. In this database, it is considered that, throughout the lifetime of the wind turbine, estimated at 20 years, a change of lubricating oil will be required once a year, which will represent two maintenance transports to the plant (one outward and one return) of approximately 200 kilometers each. In short, the lubricating oil is transported and changed once a year. This process has been defined to be simulated in Simapro by: Transport, freight, lorry 7.5-16 metric ton, EURO3 \{GLO\}| market for I APOS, U.

Wind turbine, 2MW, onshore $\{G L O\} \mid$ construction | APOS, U.
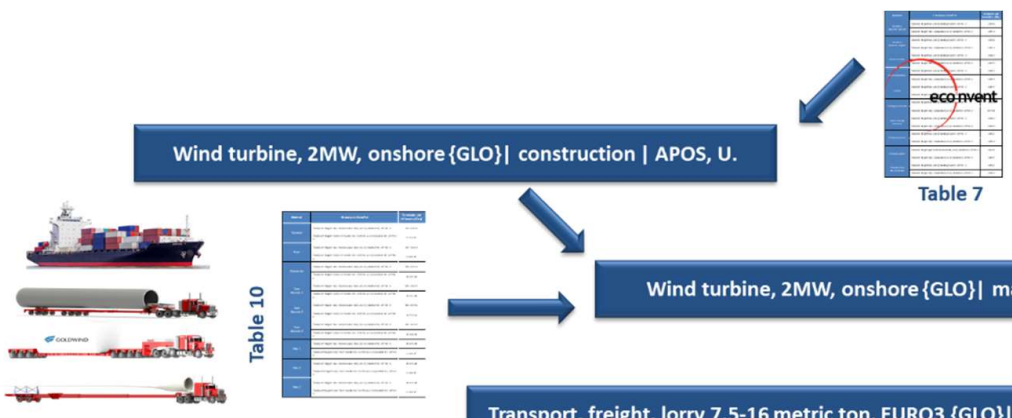

Wind turbine, 2MW, onshore $\{\mathrm{GLO}\} \mid$ market for | APOS, U

Transport, freight, lorry 7.5-16 metric ton, EURO3 \{GLO\}| market for | APOS, U

Figure 10. Schematic view of distribution stage creation in SimaPro. 


\subsection{Wind farm assembly stage}

In many LCA's, as already indicated, this stage is already considered within the construction or transportation stages; however, in order to provide clarity to this study, it will be treated as a separate point. This stage encompasses all the environmental aspects related to the construction and civil works of the wind farm, the relevant access roads, the preparation of roads for machinery access to the site, the excavation of the land, the construction of foundations, as well as all the construction work related to these concepts, including energy consumption, raw materials and waste management of the assembly process to these concepts, including energy consumption, raw materials and waste management of the assembly process.
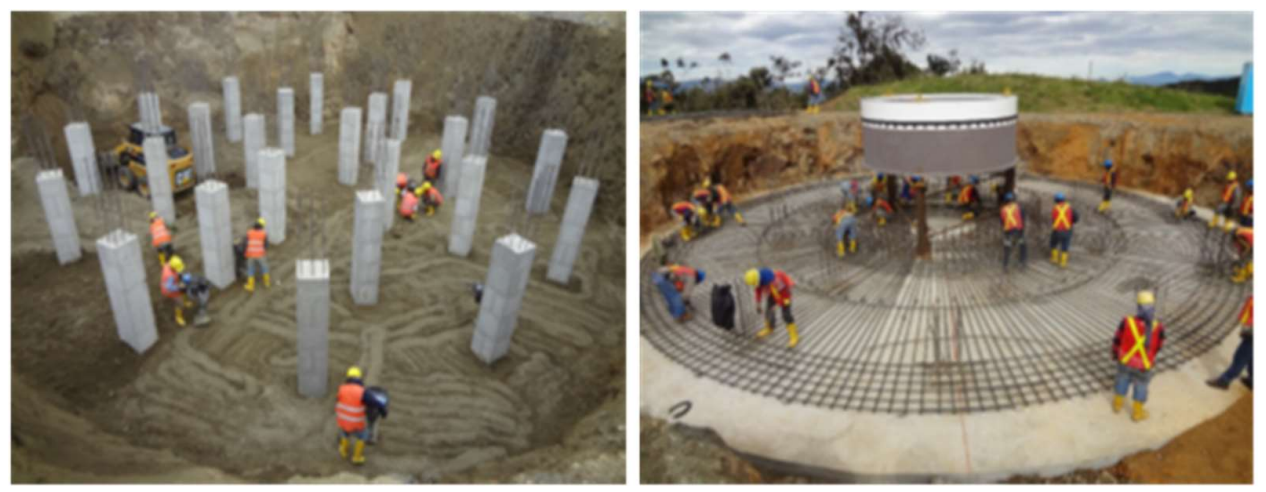

Figure 11. Execution of civil works for the Villonaco wind farm. Courtesy: GENSUR - CELEC EP.

Once all the components of each wind turbine have been manufactured in their respective manufacturing centers and transported to the place where the wind farm is planned to be deployed, the wind turbines will be assembled, whose process is represented in SimaPro, by Wind turbine, 2MW, onshore \{GLO\}| market for I APOS, $\mathrm{U}$.

In this way, it will be necessary to include the wiring that will be required to make the different electrical interconnections, the maintenance tasks that will be carried out during the entire lifetime of the referred wind farm must also be considered, as well as the different activities that must be carried out derived from them; for example, the transportation indicated in section 6.2.3.

Therefore, in order to produce $1 \mathrm{kWh}$ of electrical energy by means of wind energy in Ecuador, the inputs described in Table 11, whose data are provided by the ECOINVENT database, had to be included in the present simulation.

Table 11. Inventory for the production of $1 \mathrm{kWh}$ of electricity from wind energy in Ecuador.

\begin{tabular}{|l|c|c|}
\multicolumn{1}{|c|}{ Inputs in SimaPro } & Quantity & Unit \\
\hline Wind turbine, 2MW, onshore \{GLO\}| market for | APOS, U & $1.1636 E-8$ & $p$ \\
\hline $\begin{array}{l}\text { Wind turbine network connection, 2MW, onshore \{GLO\}| market for } \\
\text { network connection, turbine 2MW, onshore | APOS, U }\end{array}$ & $1.1636 E-8$ & $p$ \\
\hline \begin{tabular}{l} 
Lubricating oil \{GLO\}| market for | APOS, U \\
\hline $\begin{array}{l}\text { Transport, freight, lorry 7.5-16 metric ton, EURO3 \{GLO\}| market for | } \\
\text { APOS, } U\end{array}$
\end{tabular} & $1.6653 E-5$ & $\mathrm{~kg}$ \\
\hline
\end{tabular}

Although SimaPro indicates that this is a process for a 2MW turbine, it also specifies that the LCA model for this type of technology can be used as a reference for wind turbines with a capacity between $1 \mathrm{MW}$ and $3 \mathrm{MW}$; therefore, the selection of this process is valid because in our case each wind turbine has a capacity of 1.5MW. 


\subsection{Wind farm operation and maintenance stage}

The operation phase comprises 20 years of lifetime declared by IEC-61400-1, which starts from the end of the installation of the wind turbines at the site and commissioning, until the dismantling and proper management of each of its components at the end of its life. It is unlikely that a wind turbine ends its lifetime cycle without some kind of incident occurring along the way, as these can vary from a minor incident, such as the retightening of a bolt, to a corrective or even a modification.

This phase has a high environmental weighting, because it corresponds to the time interval during which the machine will produce energy. Since $1 \mathrm{kWh}$ of energy generated and fed into the grid is the functional unit of the system, it is considered that a determining factor in the environmental profile of the GW70 wind turbine, during its lifetime, is its electrical generation capacity. Thus, the sum of all the inputs of the above-mentioned processes will compose the main process on which this LCA has been focused, which has been named in SimaPro as: Electricity, high voltage $\{E C\} \mid$ electricity production, wind, 1-3MW turbine, onshore I APOS, U.

Despite the fact that the study is intended to be as close as possible to the real scenario, it has been decided that for the modelling of the present stage, all maintenance actions that will be carried out throughout the lifetime of each wind turbine will be taken into consideration, but focused exclusively on the annual change of the lubricating oil, as described in section 6.2.3.

It should be emphasized that during the operation time, the lubricating oil used will be the only waste produced by the wind technology. maintenance process for this LCA is described in SimaPro as Lubricating oil \{GLO\}| market for I APOS, U.

\section{Wind turbine, 2MW, onshore $\{\mathrm{GLO}\} \mid$ market for | APOS, U}

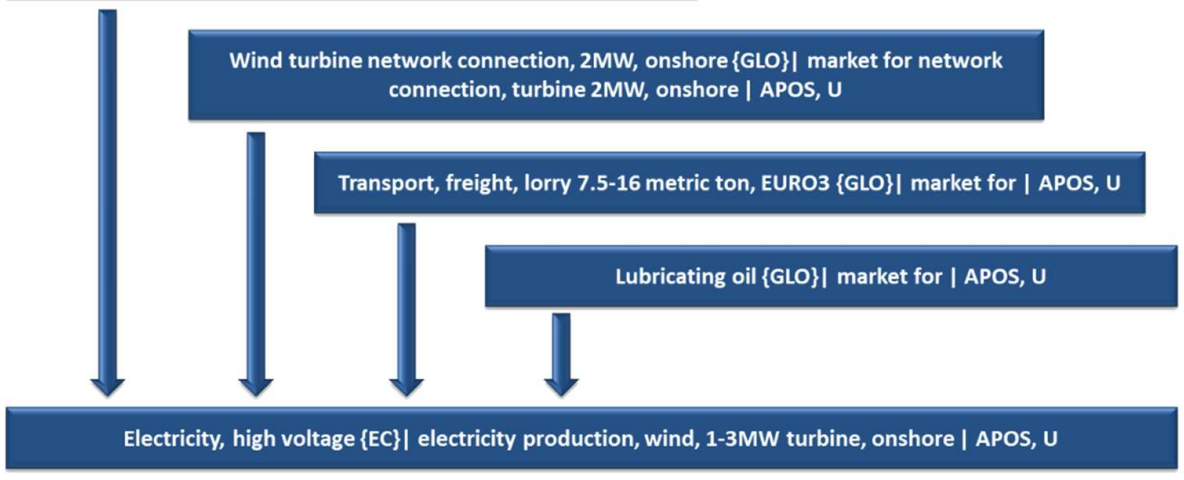

Figure 12. Schematic view of operation stage creation in SimaPro.

\subsection{Wind farm decommissioning stage}

This end-of-life stage includes the dismantling of the wind farm, as well as the transportation for waste disposal and/or recycling of the components that can be used. It considers all the environmental impacts that occur from the dismantling of the wind farm until all the materials are reused, recycled, revalued or finally disposed of. The impact associated with the transportation of all wind turbine components to their authorized manager, and the consequent impacts or credits associated with the final treatment to be applied to each component, were also taken into account.

Since there is no information available regarding the outputs resulting from the dismantling of the wind turbines, it was decided that the outputs predefined in SimaPro would be used as a basis for modeling the dismantling stage, keeping due congruence with those materials that are part of the inputs for the construction of the aforementioned wind turbine, which is part of the process Wind turbine, 2MW, onshore $\{\mathrm{GLO}\} \mid$ construction I APOS, $U$. 
Table 12. Wind turbine decommissioning outputs.

\begin{tabular}{|l|c|c|}
\hline \multicolumn{1}{|c|}{ Outputs in SimaPro } & Quantity & Unit \\
\hline Electronics scrap from control units \{GLO\}| market for | APOS, U & 438.40 & $\mathrm{~kg}$ \\
\hline Scrap copper \{RoW\}| market for scrap copper | APOS, U & $2,805.74$ & $\mathrm{~kg}$ \\
\hline Scrap steel \{RoW\}| market for scrap steel| APOS, U & $208,906.69$ & $\mathrm{~kg}$ \\
\hline Waste glass \{RoW\}| market for waste glass | APOS, U & $7,071.44$ & $\mathrm{~kg}$ \\
\hline Waste plastic, mixture \{RoW\}| market for waste plastic, mixture | APOS, U & $7,071.44$ & $\mathrm{~kg}$ \\
\hline Waste polyethylene \{RoW\}| market for waste polyethylene | APOS, U & $3,076.74$ & $\mathrm{~kg}$ \\
\hline $\begin{array}{l}\text { Waste polyethylene/polypropylene product \{RoW\}| market for waste } \\
\text { polyethylene/polypropylene product | APOS, U }\end{array}$ & $9,428.58$ & $\mathrm{~kg}$ \\
\hline $\begin{array}{l}\text { Waste reinforced concrete \{RoW\}| market for waste reinforced concrete | } \\
\text { APOS, U }\end{array}$ & $863,839.53$ & $\mathrm{~kg}$ \\
\hline
\end{tabular}

Likewise, and as mentioned at the beginning of this section, for the treatment of these wastes, the transports indicated in Table 13 will be required, remembering that this information is expressed in tons per kilometer for each kilogram of residual material.

Table 13. Transportation for the treatment of wind turbine wastes.

\begin{tabular}{|c|c|c|}
\hline Waste & Inputs in SimaPro & $\begin{array}{c}\text { Traffic unit } \\
\text { [ton-km] }\end{array}$ \\
\hline \multirow{2}{*}{ Electronic components } & Transport, freight train $\{G L O\} \mid$ market group for $\mid A P O S, U$ & 0.112 \\
\hline & Transport, freight, lorry, unspecified $\{G L O\} \mid$ market for $\mid A P O S, U$ & 0.1932 \\
\hline \multirow{2}{*}{ Aluminum } & Transport, freight train $\{G L O\} \mid$ market group for $\mid A P O S, U$ & 0.112 \\
\hline & Transport, freight, lorry, unspecified $\{G L O\} \mid$ market for $\mid A P O S, U$ & 0.1932 \\
\hline \multirow{2}{*}{ Copper } & Transport, freight train $\{$ RoW $\} \mid$ market for $\mid A P O S, U$ & 0.00484 \\
\hline & Transport, freight, lorry, unspecified $\{G L O\} \mid$ market for $\mid$ APOS, $U$ & 0.1932 \\
\hline \multirow{2}{*}{ Steel } & Transport, freight train $\{$ RoW $\} \mid$ market for $\mid A P O S, U$ & 0.00484 \\
\hline & Transport, freight, lorry, unspecified $\{G L O\} \mid$ market for $\mid A P O S, U$ & 0.1932 \\
\hline \multirow{2}{*}{ Glass } & Transport, freight train $\{$ RoW $\} \mid$ market for $\mid A P O S, U$ & 0.00484 \\
\hline & Transport, freight, lorry, unspecified $\{G L O\} \mid$ market for $\mid A P O S, U$ & 0.1932 \\
\hline \multirow{2}{*}{ Plastic } & Transport, freight train $\{R o W\} \mid$ market for $\mid A P O S, U$ & 0.00484 \\
\hline & Transport, freight, lorry, unspecified $\{G L O\} \mid$ market for $\mid A P O S, U$ & 0.1932 \\
\hline \multirow{2}{*}{ Polyethylene } & Transport, freight train $\{$ RoW $\} \mid$ market for $\mid A P O S, U$ & 0.00484 \\
\hline & Transport, freight, lorry, unspecified $\{G L O\} \mid$ market for $\mid A P O S, U$ & 0.1932 \\
\hline \multirow{2}{*}{ Polyethylene/Polypropylene } & Transport, freight train $\{$ RoW\}| market for $\mid A P O S, U$ & 0.00484 \\
\hline & Transport, freight, lorry, unspecified $\{G L O\} \mid$ market for $\mid$ APOS, $U$ & 0.1932 \\
\hline \multirow{2}{*}{ Concrete } & Transport, freight train $\{$ RoW $\} \mid$ market for $\mid A P O S, U$ & 0.00484 \\
\hline & Transport, freight, lorry, unspecified $\{G L O\} \mid$ market for $\mid A P O S, U$ & 0.1932 \\
\hline
\end{tabular}

For this LCA, metal waste (ferrous and non-ferrous) can be recycled in its entirety. Regarding plastic corresponding to fiberglass, it can be recycled in a range between $80 \%$ and $90 \%$. Electrical/electronic components are 50\% recycled, and electrical cables are almost entirely recycled. Finally, it should be noted that it is not currently possible to recycle wind turbine blades; therefore, when their lifetime is over, the blades will have to be dismantled into smaller pieces, which will be taken to controlled waste deposits. [24] 


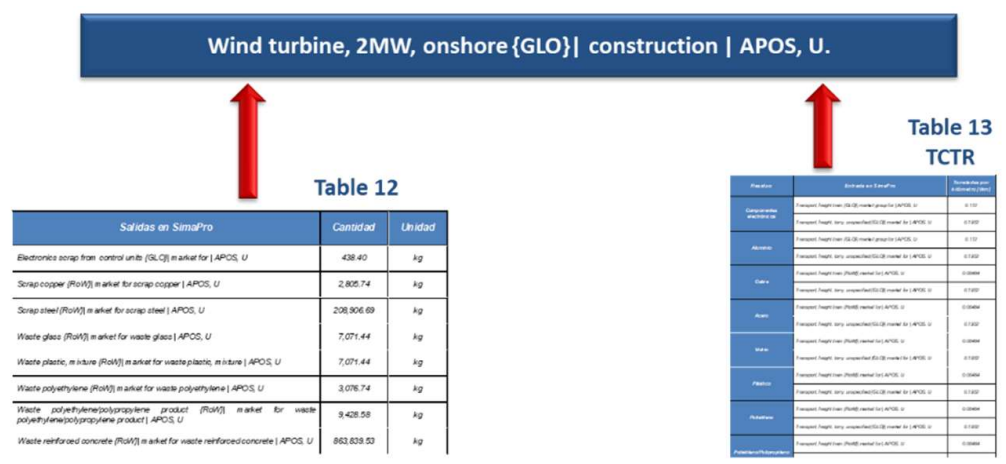

Figure 13. Schematic view of Decommissioning and end-of-life stage.

\section{Annual energy production}

In the region where the Villonaco wind farm is located, there is a marked seasonality with strong winds during the months of June to October, as shown in Figure 14. Even though the province of Loja is located on the equinoctial equator, the topography of the mountains in the sector generates areas with high energy density.

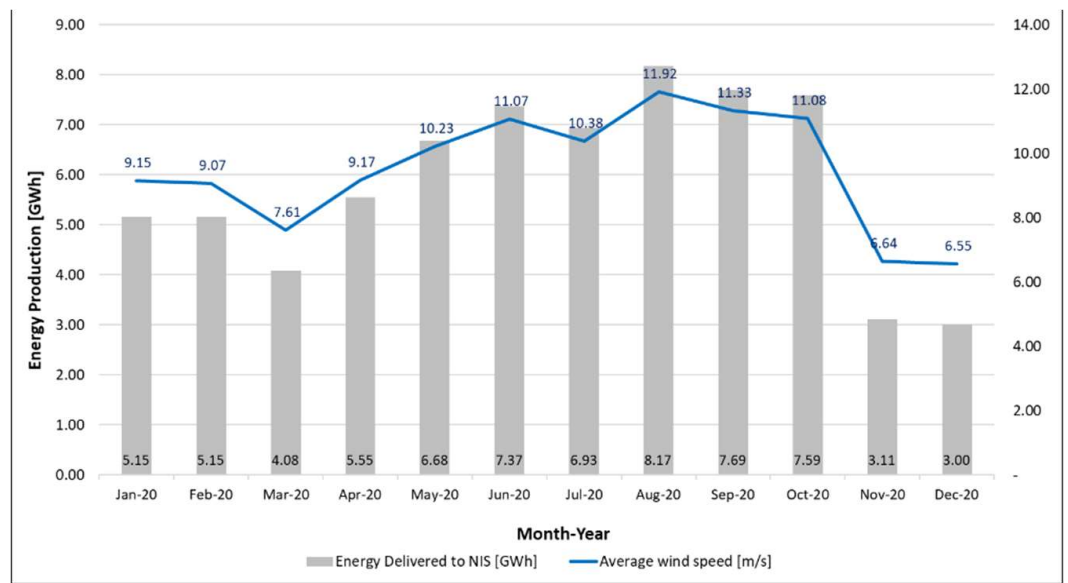

Figure 14. Year 2020, Energy delivered to NIS and monthly average wind speed. Source: CELEC EP.

Based on studies carried out, it is considered that this region has adequate conditions for wind energy exploitation, presenting velocity distributions close to Weibull distributions with shape parameter $\mathrm{k}=2$. The main wind energy directions of this area are ENE and $\mathrm{E}$, so the main wind energy direction is relatively concentrated and the wind energy decreases proportionally to the decrease in density that occurs with altitude.

\begin{tabular}{|c|c|c|c|}
\hline $\begin{array}{c}\text { Wind speed } \\
{[\mathrm{m} / \mathrm{s}]}\end{array}$ & $\begin{array}{c}\text { Power } \\
{[\mathrm{kW}]}\end{array}$ & $\begin{array}{c}\text { Wind speed } \\
{[\mathrm{m} / \mathrm{s}]}\end{array}$ & $\begin{array}{c}\text { Power } \\
{[\mathrm{kW}]}\end{array}$ \\
\hline 0 & 0 & 13 & 1,227 \\
\hline 1 & 0 & 14 & 1,361 \\
\hline 2 & 0 & 15 & 1,432 \\
\hline 3 & 8 & 16 & 1,469 \\
\hline 4 & 35 & 17 & 1,496 \\
\hline 5 & 77 & 18 & 1,496 \\
\hline 6 & 139 & 19 & 1,498 \\
\hline 7 & 226 & 20 & 1,499 \\
\hline 8 & 340 & 21 & 1,500 \\
\hline 9 & 479 & 22 & 1,500 \\
\hline 10 & 644 & 23 & 1,500 \\
\hline 11 & 830 & 24 & 1,500 \\
\hline 12 & 1,031 & 25 & 1,500 \\
\hline & & & \\
\hline
\end{tabular}

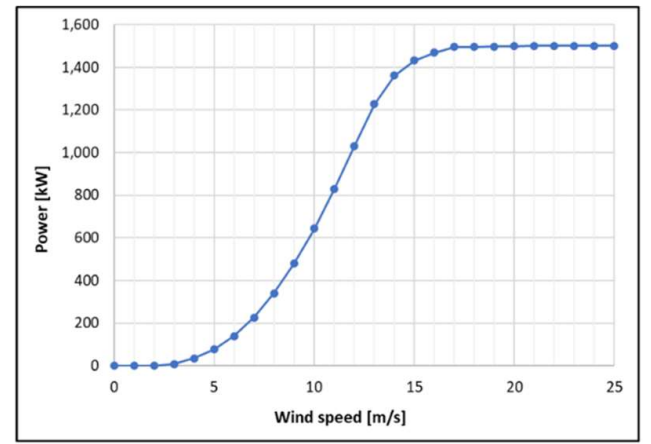

Figure 15. Power curve of GW70/1500 wind turbine. Courtesy: Goldwind Co., Ltd. [25] 
Based on the information obtained from the Power Curve of the GW70/1500kW wind turbine, shown in Figure 15 and provided by the manufacturer Goldwind, the energy produced by this generation unit will be determined, considering that the location where it is located would have an annual average wind speed at the hub height of $9.78 \mathrm{~m} / \mathrm{s}$, assuming a Rayleigh speed distribution (shape parameter, $\mathrm{k}=2$ ) and a lifetime of 20 years, according to the IEC-61400-1 standard.

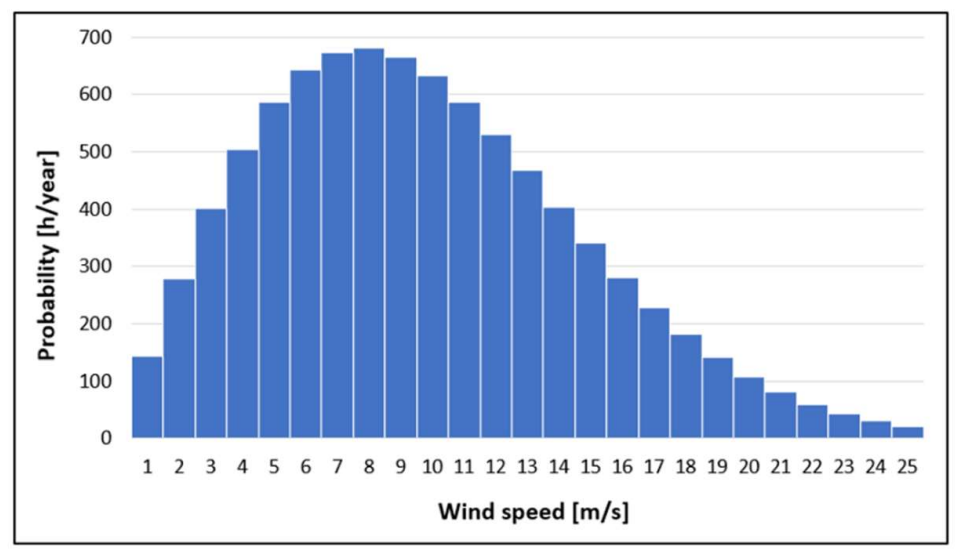

Figure 16. Probability distribution of annual wind speed with $\langle\mathrm{v}>=9.78 \mathrm{~m} / \mathrm{s}$ and $\mathrm{k}=2$.

For each wind turbine of the Villonaco Wind Farm, the annual energy production (AEP) obtained from the Power Curve and the Probability distribution of annual wind speed, shown in Figure 16, has a value of 5,655.73 MWh, producing over its lifetime $113,114.68 \mathrm{MWh}$, whose Energy distribution of annual wind speed is shown in Figure 17.

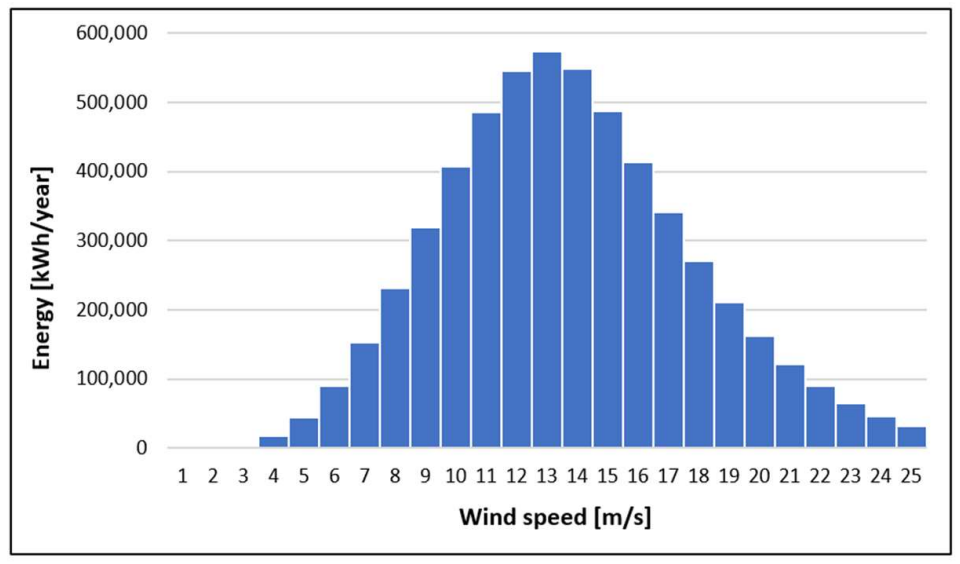

Figure 17. Energy distribution of annual wind speed with $<\mathrm{v}>=9.78 \mathrm{~m} / \mathrm{s}$ and $\mathrm{k}=2$.

\section{Results}

\subsection{Environmental Impact in the climate change category}

As can be seen in the diagram or network tree shown in Figure 18, for the production of $1 \mathrm{kWh}$ of electricity from wind technology in Ecuador, a total of $0.0155 \mathrm{~kg}$ of $\mathrm{CO}_{2}$ eq are emitted. It can be observed that most of this emission, that is, $0.0147 \mathrm{~kg} \mathrm{CO}_{2}$ eq, corresponds to the construction process of the wind turbine itself, and only $0.0005 \mathrm{~kg} \mathrm{CO}$ eq, to the transportation of the components.

Additionally, the sub-processes with the highest contribution to carbon dioxide emissions in wind power generation are also steel production, followed by fiberglass and the construction of the access road to the wind farm. 


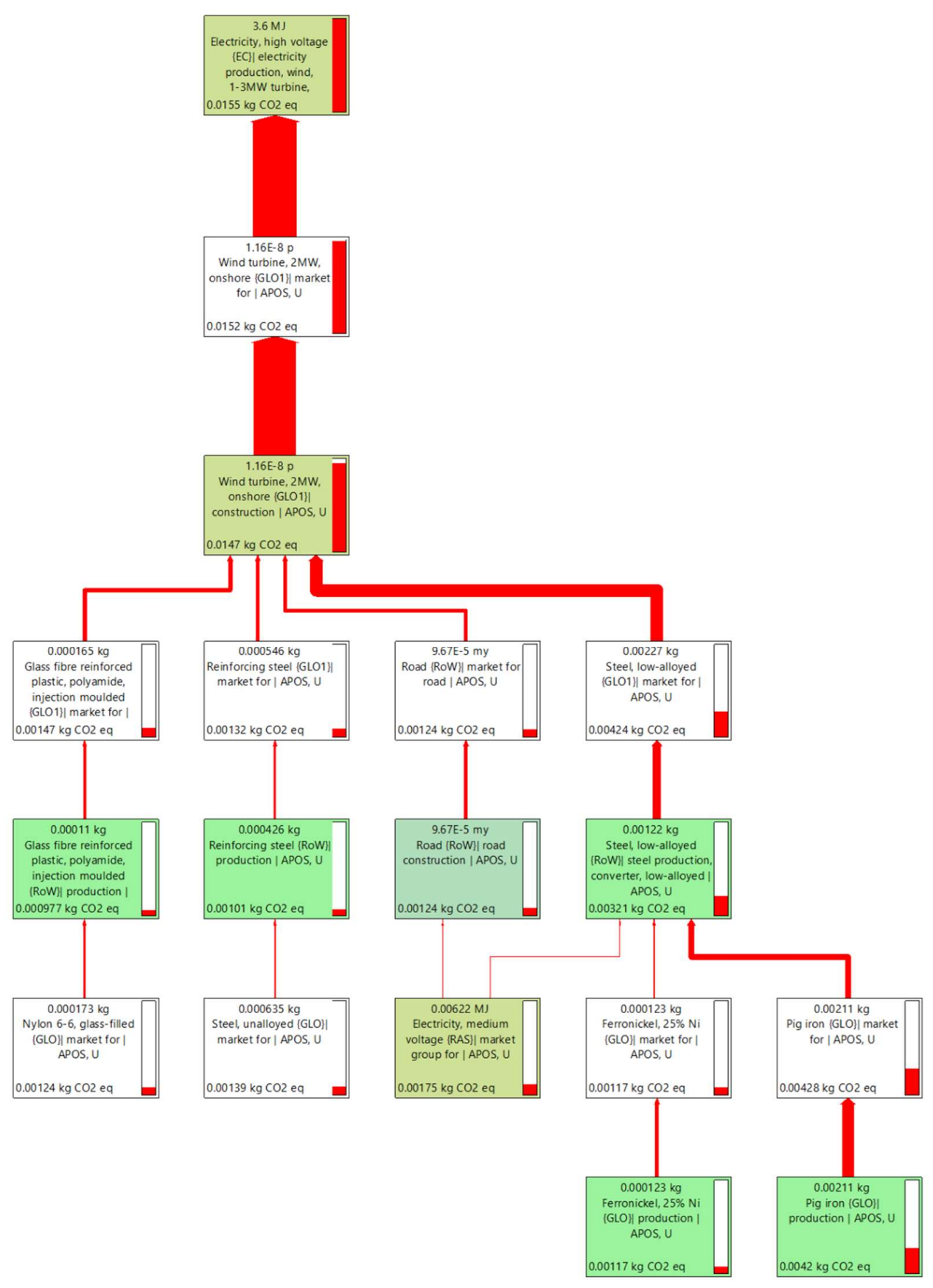

Figure 18. Electricity, high voltage $\{E C\} \mid$ electricity production, wind, 1-3MW turbine, onshore I APOS, U.

\subsection{Environmental Impact in the water footprint category}

As can be seen in the diagram or network tree shown in Figure 19, for the production of $1 \mathrm{kWh}$ of electricity from wind technology in Ecuador, a total of $8.72 \times 10^{-5} \mathrm{~m}^{3}$ of water is required. It can be seen that most of this volume corresponds to the wind turbine construction process. Additionally, in this analysis, the connection to the electrical grid is more important than in the carbon footprint; this is due to the requirement of the vital liquid for the treatment of the waste produced by the plastic of the electrical conductors. 


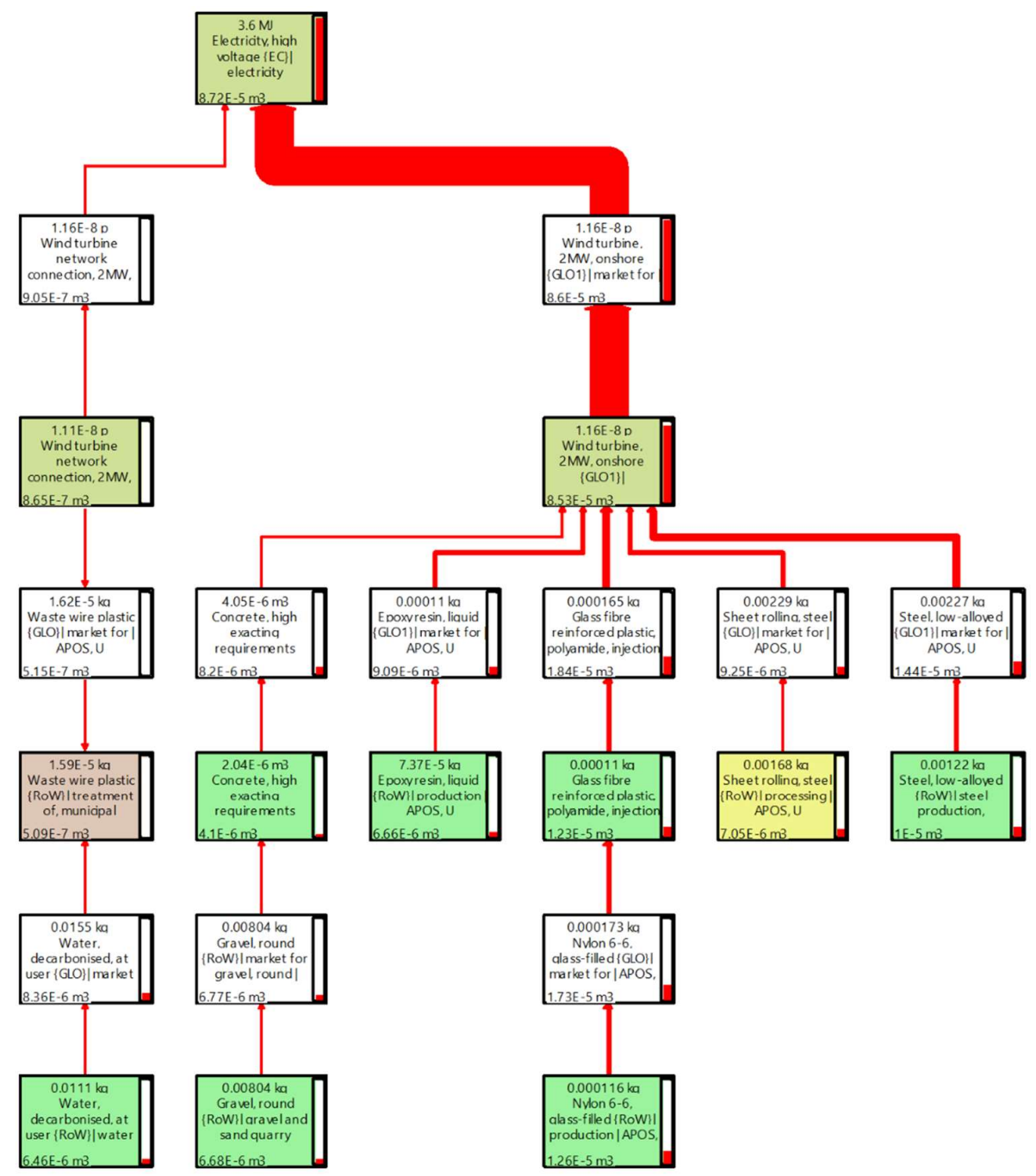

Figure 19. Electricity, high voltage $\{E C\} \mid$ electricity production, wind, $1-3 M W$ turbine, onshore I APOS, U.

\subsection{Cumulative energy demand}

CED is a unique scoring methodology, by means of which it is possible to determine the amount of energy consumed during the entire life cycle of the wind turbine, considering all its stages, from the procurement of raw materials and components, to the end-oflife and decommissioning of the wind turbine.

In this LCA, the result provided by SimaPro is obtained in MJeq and, depending on the analysis to be carried out, it can be presented globally or broken down by the type of source from which the energy was obtained. For the purposes of this study, it is only of interest to show it in its global form, i.e., as shown in Table 14. Thus, in Ecuador, a Goldwind GW70/1500 wind turbine will require 0.215 MJeq of energy, over its entire life cycle, to produce $1 \mathrm{kWh}$ of electricity.

Table 14. Cumulative Energy Demand for GW70/1500 wind turbine.

\begin{tabular}{|c|c|c|}
\hline Impact category & Total life cycle & Unit \\
\hline Cumulative Energy Demand & 0.215 & $M_{\text {eq }}$ \\
\hline
\end{tabular}




\section{Conclusions}

- In order to produce $1 \mathrm{kWh}$ of energy, it requires $1.1636 \times 10^{-8}$ wind turbines, with the technical characteristics stated in this study, which implies that it should operate 2,865 $\mathrm{h} /$ year, concluding that this wind farm is located in an appropriate place and exploited correctly.

- After the complete LCA of the renewable wind energy technology in Ecuador, it is concluded that carbon dioxide emissions and water consumption, during the transportation stage, can be considered practically negligible for this energy source, where a large part would be present in the construction and assembly stages, which represents a contribution of $94.84 \%$ in terms of $\mathrm{CO}_{2}$ emissions and $97.82 \%$ in terms of water consumption, as summarized below.

Table 15. Distribution of Carbon Footprint and Water Footprint by functional stages.

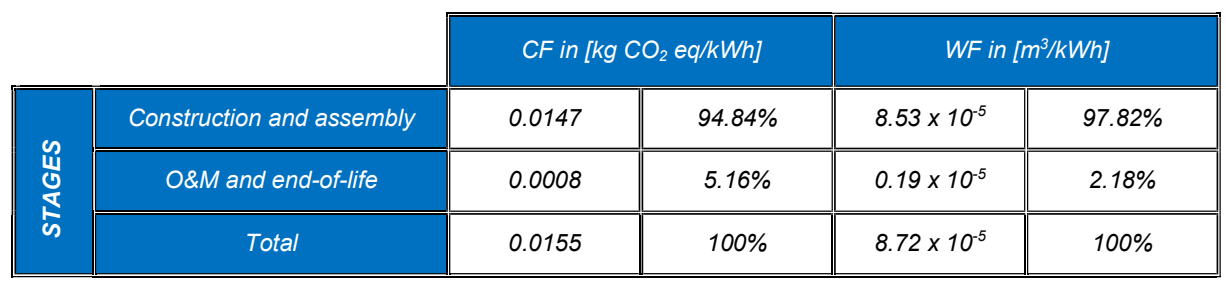

- Greenhouse gas emissions (GHG) over the life cycle of solar, wind and nuclear technologies are considerably lower and less variable than emissions from technologies based on the combustion of natural gas and coal. The wind power source has one of the smallest carbon footprints, between 11 and $14 \mathrm{~g}$ of $\mathrm{CO}_{2} \mathrm{eq} / \mathrm{kWh}$, and only surpassed by nuclear power. The same can be said of the behavior of his water footprint. According to the LCA applied to the Villonaco Wind Central, located in Loja, Ecuador, the carbon footprint and water footprint reached the value of $15.5 \mathrm{~g} \mathrm{CO}_{2} \mathrm{eq} / \mathrm{kWh}$ and $8.72 \times 10^{-5} \mathrm{~m}^{3} / \mathrm{kWh}$, respectively, which are adequately related to the studies conducted by NREL and BNL.

Table 16. Carbon Footprint and Water Footprint for different energy sources [26,27].

\begin{tabular}{|c|c|c|c|}
\hline & Source of energy & $\mathrm{CF}$ in $\mathrm{g} \mathrm{CO} \mathrm{CO}_{2} \mathrm{eq} / \mathrm{kWh}$ & $W F$ in $m^{3} / k W h$ \\
\hline \multirow{5}{*}{ 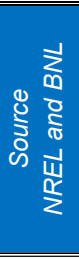 } & Coal & 980 & $2.84 \times 10^{-4}-75.60 \times 10^{-4}$ \\
\hline & Natural Gas & 465 & $2.74 \times 10^{-4}-44.64 \times 10^{-4}$ \\
\hline & Solar & $14-45$ & $2.30 \times 10^{-5}-1.09 \times 10^{-3}$ \\
\hline & Nuclear & 12 & $6.48 \times 10^{-5}-5.22 \times 10^{-3}$ \\
\hline & Wind & $11-14$ & $7.2 \times 10^{-7}-75.6 \times 10^{-4}$ \\
\hline & Villonaco & 15.5 & $8.72 \times 10^{-5}$ \\
\hline
\end{tabular}

- Energy Return on Investment (EROI) is known as the ratio or relationship between the total amount of energy that a given energy source is capable of producing, in our case wind energy, and the amount of energy that must be used or contributed to exploit that energy resource. Thus, the necessary information is summarized in Table 17. For the present case it is shown that it takes 1.19 years for a wind turbine to generate all the electricity it will consume during its entire lifetime, which is 20 years. Therefore, the GW70/1500 wind turbine is capable of generating 16.74 times the same 
amount of energy that it would consume during its entire life cycle; that is, the energy consumed from the extraction of raw materials and components to the end of life and its final dismantling process.

Table 17. CED, EROI and PT for GW70/1500 wind turbine.

\begin{tabular}{|c|c||}
\hline DESCRIPTION FOR GW70/1500 & IEC - II $<v>=9.78$ [m/s] \\
\hline Cumulative Energy Demand (CED) [MWh eq] & $6,755.46$ \\
\hline Energy Production during lifetime [MWh] & $113,114.68$ \\
\hline Energy Return on Investment (EROI) & 16.74 \\
\hline Payback Time (PT) [Years] & 1.19 \\
\hline Payback Time (PT) [Months] & 14.33 \\
\hline
\end{tabular}

- In relation to conventional sources of electricity, the deployment of wind farms is, undisputable, an environmental improvement. Not only in Ecuador, but also in several countries around the world, and due to climate change vulnerability issues, it is essential to diversify the energy mix by considering non-conventional renewable sources such as solar or wind power; this being the only way to reduce both the carbon and water footprint of our energy supply. One of the key challenges will undoubtedly be to consider efficient energy storage to respond in time to supply and demand.

Funding: This research received no external funding.

Data Availability Statement: The data used in this study can be obtained by contacting the corresponding author.

Acknowledgments: The author is very grateful to the Strategic Public Company Corporación Eléctrica del Ecuador, through its Business Unit CELEC EP-GENSUR for providing data necessary for this study, also thank to PRé Sustainability B.V. for having provided a 1-year non-OECD SimaPro Faculty license, the world's leading life cycle assessment (LCA) software. Finally, wishes to sincerely thank to Dr. Miguel Villarrubia López and Andrés Caballero Martínez, MSc. for their reviews and critical comments.

Conflicts of Interest: The author declares no conflict of interest.

\section{Abbreviations}

\begin{tabular}{|c|c|c|c|}
\hline Acronyms & & Units & \\
\hline APOS & Allocation at the point of substitution & GW & Gigawatt \\
\hline$B N L$ & Brookhaven National Laboratory & $K g$ & kilograms \\
\hline CED & Cumulative Energy Demand & $k m^{2}$ & Square kilometer \\
\hline $\mathrm{CO}_{2} \mathrm{eq}$ & Carbon dioxide equivalent & m.a.s.l. & Meters above sea level \\
\hline EROI & Energy Return on Investment & $m^{3} / k W h$ & Cubic meter per $\mathrm{kWh}$ \\
\hline GLO & Global (region code) & $M B O E$ & Millions of barrels of oil equivalent \\
\hline GWEC & Global Wind Energy Council & $M J_{e q}$ & Megajoule equivalent \\
\hline IEC & International Electrotechnical Commission & Mtoe & Millions of tons of oil equivalent \\
\hline IIGE & $\begin{array}{l}\text { Instituto de Investigación Geológico y Energé- } \\
\text { tico, Ecuador. }\end{array}$ & $M W$ & Megawatt \\
\hline$L C A$ & Life Cycle Assessment & $M W h$ & Megawatt-hour \\
\hline NIS & National Interconnected System & My & miles year \\
\hline NREL & National Renewable Energy Laboratory & ton- $k m$ & Traffic unit, tons-kilometer \\
\hline$O E C D$ & $\begin{array}{l}\text { Organization for Economic Co-operation and } \\
\text { Development }\end{array}$ & TWh/year & Terawatt-hour per year \\
\hline RoW & Rest-of-the-World (region code) & $\begin{array}{l}g \mathrm{CO}_{2} \\
e q / k W h\end{array}$ & Grams of $\mathrm{CO}_{2}$ eq per $\mathrm{kWh}$ \\
\hline
\end{tabular}




\section{References}

1. C. Ghenai, Life Cycle Analysis of Wind Turbine, Sustainable Development - Energy, Engineering and Technologies Manufacturing and Environment, P. C. Ghenai, Ed., InTech, 2012, pp. 19-32.

2. GWEC Global Wind Energy Council, "Global Wind Report 2021," GWEC Global Wind Energy Council, 2021.

3. E. Martínez, F. Sanz, S. Pellegrini, E. Jiménez and J. Blanco, "Life-cycle assessment of a 2-MW rated power wind turbine: CML method," The International Journal of Life Cycle Assessment, vol. 14, no. 1, pp. 52-63, 2009.

4. B. Guezuraga, R. Zauner and W. Pölz, "Life cycle assessment of two different 2 MW class wind turbines," Renewable Energy, vol. 37, no. 1, pp. 37-44, January 2012.

5. United Nations Educational, Scientific and Cultural Organization, "Sustainable Development," UNESCO, [Online]. Available: https://en.unesco.org/themes/education-sustainable-development/what-is-esd/sd. [Accessed 2019].

6. B. Tremeac and F. Meunier, "Life cycle analysis of 4.5 MW and $250 \mathrm{~W}$ wind turbines," Renewable and Sustainable Energy Reviews, vol. 13, no. 8, pp. 2104-2110, October 2009.

7. P. Razdan and P. Garrett, "Life Cycle Assessment of Electricity Production from an onshore V100-2.0 MW Wind Plant," Aarhus, 2017.

8. S. Álvarez Gallego, La huella de carbono y el análisis de ciclo de vida, Primera ed., AENOR INTERNACIONAL, S.A.U., 2017, p. 111.

9. International Electrotechnical Commission, "IEC 61400-1," IEC Central Office, GENEVA, 2005.

10. Ministry of Energy and Non-Renewable Natural Resources, "National Energy Balance," Quito, 2019.

11. Agency for the Regulation and Control of Energy and Non-Renewable Natural Resources, "Annual and Multiannual Statistics of the Ecuadorian Electricity Sector," ARCONEL, Quito, 2019.

12. Dongfang Electric International Corporation, "Descripción General Tecnológica para Aerogenerador de Accionamiento Directo D3200-155," DEC, 2020.

13. Ministry of Electricity and Renewable Energy, "Wind Atlas of Ecuador," MEER, 2014.

14. Ministry of Energy and Non-Renewable Natural Resources, "Villonaco 2\&3 Wind Farm Project," MERNNR, 2020.

15. Goldwind, GW70/1500 Wind Turbine Technical Description, Ürümqi: Xin Jiang Goldwind Science \& Technology Co.,Ltd., p. 11.

16. GoldWind, PMDD Wind Turbine 1.5 MW, Xinjiang Goldwind Science \& Technology Co., Ltd, p. 8.

17. J. R. Muro Pereg and J. F. de la Hoz Múgica, "Análisis de Ciclo de Vida de 1kWh Generado por un Parque Eólico Onshore GAMESA G90-2.0MW," 2013.

18. European Commission, Joint Research Centre, IES, "European Platform on Life Cycle Assessment," February 2012. [Online]. Available: https://eplca.jrc.ec.europa.eu/uploads/LCIA-characterization-factors-of-the-ILCD.pdf. [Accessed March 2019].

19. M. M. Mekonnen, P. Gerbens-Leenes and A. Y. Hoekstra, "Royal Society of Chemistry," March 9th, 2015. [Online]. Available: https://waterfootprint.org/media/downloads/Mekonnen-et-al-2015.pdf.

20. P. P. Miglieta, D. Morrone and F. De Leo, "The Water Footprint Assessment of Electricity Production: An Overview of the Economic-Water-Energy Nexus in Italy," Sustainability, vol. 10, no. 1, p. 228, January 17 2018.

21. M. Berger, R. Van der Ent, S. Eisner, V. Bach and M. Finkbeiner, "Water Accounting and Vulnerability Evaluation (WAVE): Considering Atmospheric Evaporation Recycling and the Risk of Freshwater Depletion in Water Footprinting," Environmental Science Technology, vol. 48, no. 8, pp. 4521-4528, 24 March 2014.

22. J. B. Guinée, M. Gorreé, R. Heijungs, G. Huppes and M. A. Huijbregts, "Life cycle assessment: An operational guide to ISO standards," 2001.

23. Ecoinvent, 2018. [Online]. Available: https://www.ecoinvent.org/.

24. Elsam Engineering A/S, "Life Cycle Assessment of offshore and onshore sited wind farms," Vestas Wind Systems A/S, Aarhus, 2004.

25. GOLDWIND SCIENCE \& TECHNOLOGY CO., LTD/CHINA TIANYUAN NEW ENERGY TECHNOLOGY CO.,LTD, "Micrositing Report of Villonaco Wind Farm, Ecuador," Tian Yuan Creation, China, 2013.

26. V. Schipani, "FactCheck," 14 March 2018. [Online]. Available: https://www.factcheck.org/2018/03/wind-energys-carbonfootprint/.

27. P. Garvin Heath, "NREL National Renewable Energy Laboratory," January 13 ${ }^{\text {th }}$, 2016. [Online]. Available: https://www.nrel.gov/docs/fy16osti/65645.pdf. 